\title{
Thermodynamics of Molybdenum Trioxide Encapsulated in Zeolite Y
}

\author{
Xianghui Zhang ${ }^{1}$, Andrew Strzelecki ${ }^{1}$, Cody Cockreham $^{1}$, Vitaliy Goncharov ${ }^{1}$, Houqian \\ $\mathrm{Li}^{1}$, Junming Sun ${ }^{1}$, Hui Sun ${ }^{2}$, Xiaofeng Guo ${ }^{1}$, Hongwu Xu${ }^{3}$, Su Ha${ }^{1}$, Baodong Wang ${ }^{4}$, Yong \\ $\mathrm{Wang}^{1}$, and $\mathrm{Di} \mathrm{Wu}^{1}$ \\ ${ }^{1}$ Washington State University \\ ${ }^{2}$ East China University of Science and Technology \\ ${ }^{3}$ Los Alamos National Laboratory \\ ${ }^{4}$ National Institute of Clean and Low Carbon Energy
}

October 22, 2021

\begin{abstract}
Zeolites with encapsulated transition metal species are extensively applied in the chemical industry as heterogenous catalysts for favorable kinetic pathways. To elucidate the energetic insights into formation of subnano-sized molybdenum trioxide $\left(\mathrm{MoO}_{3}\right)$ encapsulated/confined in zeolite Y (FAU) from constituent oxides, we performed a systematic experimental thermodynamic study using high temperature oxide melt solution calorimetry as the major tool. Specifically, the formation enthalpy of each $\mathrm{MoO}_{3} / \mathrm{FAU}$ is less endothermic than corresponding zeolite $\mathrm{Y}$, suggesting enhanced thermodynamic stability. As Si/Al ratio increases, the enthalpies of formation of $\mathrm{MoO}_{3} / \mathrm{FAU}$ with identical loading ( $5 \mathrm{Mo}-\mathrm{wt} \%$ ) tend to be less endothermic, ranging from $61.1 \pm 1.8(\mathrm{Si} / \mathrm{Al}=2.9)$ to $32.8 \pm 1.4 \mathrm{~kJ} / \mathrm{mol} \mathrm{TO} 2(\mathrm{Si} / \mathrm{Al}=45.6)$. Coupled with spectroscopic, structural and morphological characterizations, we revealed intricate energetics of $\mathrm{MoO}_{3}$ - zeolite Y guest - host interactions likely determined by the subtle redox and/or phase evolutions of encapsulated $\mathrm{MoO}_{3}$.
\end{abstract}

\section{Thermodynamics of Molybdenum Trioxide $\left(\mathrm{MoO}_{3}\right)$ Encapsulated in Zeolite $\mathrm{Y}$}

Xianghui Zhang a,b, Andrew C. Strzelecki ${ }^{\mathrm{a}, \mathrm{c}, \mathrm{d}}$, Cody B. Cockreham ${ }^{\mathrm{a}, \mathrm{b}, \mathrm{e}}$, Vitaliy G. Goncharov ${ }^{\mathrm{a}, \mathrm{c}, \mathrm{e}}$, Houqian $\mathrm{Li}^{\mathrm{b}}$, Junming Sun ${ }^{\mathrm{b}}$, Hui Sun ${ }^{\mathrm{f}, \mathrm{g}}$, Xiaofeng Guo ${ }^{\mathrm{a}, \mathrm{c}, \mathrm{d}}$, Hongwu Xu ${ }^{\mathrm{e}}$, $\mathrm{Ha} \mathrm{Su}^{\mathrm{b}}$, Baodong Wang ${ }^{\text {h }}$, Yong Wang b,i , Di Wu ${ }^{a, b, c, d, *}$

${ }^{a}$ Alexandra Navrotsky Institute for Experimental Thermodynamics, Washington State University, Pullman, Washington 99163, United States

b The Gene and Linda Voiland School of Chemical Engineering and Bioengineering, Washington State University, Pullman, Washington 99163, United States

${ }^{c}$ Department of Chemistry, Washington State University, Pullman, Washington 99163, United States

d Materials Science and Engineering, Washington State University, Pullman, Washington 99163, United States

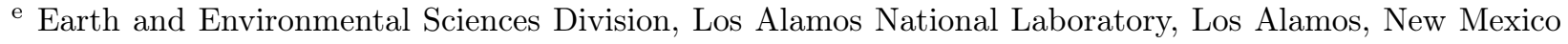
87545

${ }^{\mathrm{f}}$ Petroleum Processing Research Center, East China University of Science and Technology, Shanghai 200237, China 
g International Joint Research Center of Green Energy Chemical Engineering, East China University of Science and Technology, Shanghai 200237, China

h National Institute of Clean-and-Low-Carbon Energy, Beijing, 102211, China

${ }^{\mathrm{i}}$ Institute for Integrated Catalysis, Pacific Northwest National Laboratory, Richland, Washington 99163, United States

Corresponding Author Email:

Di Wu,d.wu@wsu.edu

\begin{abstract}
Zeolites with encapsulated transition metal species are extensively applied in the chemical industry as heterogenous catalysts for favorable kinetic pathways. To elucidate the energetic insights into formation of subnano-sized molybdenum trioxide $\left(\mathrm{MoO}_{3}\right)$ encapsulated/confined in zeolite $\mathrm{Y}$ (FAU) from constituent oxides, we performed a systematic experimental thermodynamic study using high temperature oxide melt solution calorimetry as the major tool. Specifically, the formation enthalpy of each $\mathrm{MoO}_{3} / \mathrm{FAU}$ is less endothermic than corresponding zeolite $\mathrm{Y}$, suggesting enhanced thermodynamic stability. As $\mathrm{Si} / \mathrm{Al}$ ratio increases, the enthalpies of formation of $\mathrm{MoO}_{3} / \mathrm{FAU}$ with identical loading ( $5 \mathrm{Mo}-\mathrm{wt} \%$ ) tend to be less endothermic, ranging from $61.1 \pm 1.8(\mathrm{Si} / \mathrm{Al}=2.9)$ to $32.8 \pm 1.4 \mathrm{~kJ} / \mathrm{mol} \mathrm{TO} 2(\mathrm{Si} / \mathrm{Al}=45.6)$. Coupled with spectroscopic, structural and morphological characterizations, we revealed intricate energetics of $\mathrm{MoO}_{3}$ - zeolite Y guest host interactions likely determined by the subtle redox and/or phase evolutions of encapsulated $\mathrm{MoO}_{3}$.
\end{abstract}

\title{
Introduction
}

For the foreseeable future, carbon-based fuels, such as natural gas, petroleum, coal, and biomass, will continue to be a significant part of our energy infrastructure, and interfacially engineered heterogeneous catalytic materials relying on transition metal (TM) species will continue to play a critical role in meeting our daily energy needs. ${ }^{1-4}$ It has been demonstrated that supported or confined TMs, their oxide (TMO), carbide (TMC) and nitride (TMN) particles exhibit promising performance with high activity and selectivity in selective conversion of methane, ${ }^{5-8}$ low-temperature CO conversion, ${ }^{9,10}$ selective hydrogenation/dehydrogenation, 11-14 bio-oil conversion and upgrading, ${ }^{15-18}$ and water-gas shift reaction. ${ }^{19,20}$ Existing literature on heterogeneous catalytic materials primarily emphasize their outstanding performance and complexity in kinetics and reaction mechanisms. Meanwhile, the rapid development of catalyst synthesis has outran the existing thermodynamic database of materials that mainly documents the thermochemical properties of homogeneous systems, such as solid solutions. ${ }^{21}$ There are currently no systematic experimental thermodynamic data on formation energetics of interfacially supported and spatially confined/encapsulated TM species that feature solid - solid interfaces and grain boundaries. ${ }^{21}$ Moreover, the energetics of such particle - support or guest - host interfacial interactions, put simply, "the energetic cost of being small", is unknown. ${ }^{21}$ The longterm goal of our group is to narrow such widening knowledge gap by carrying out thermodynamic studies on materials with interfacially stabilized subnano and nanoparticles using calorimetry as the fundamental tool. We expect that such experimentally determined energetic insights will enable enhanced understanding for further development of inexpensive and more sustainable energy harvesting and conversion materials, nanostructured catalysts and sorbents using earth-abundant elements.

The current focus of our group is on thermodynamics of zeolites with encapsulated TM-based particles/clusters. Zeolites are framework aluminosilicates with open microporosity constructed by corner-sharing tetrahedron units, in which the $\mathrm{T}$ atom is silicon $(\mathrm{Si})$ or aluminum $(\mathrm{Al})$. Substitution of $\mathrm{Si}^{4+}$ by $\mathrm{Al}^{3+}$ enables negatively charged framework structures with Brønsted and Lewis acidity. Owing to their crystalline open framework topologies and tunable surface sites, zeolites offer ideal platforms to support TM species for heterogeneous catalysis with high activity and shape selectivity. ${ }^{22,23}$ Employing a suite of highly customized calorimeters, in collaboration with Drs. Davis and Zones, the Navrotsky Group pioneered research on thermodynamics of pure zeolites since 1990s, in which the cation - water - zeolite interplays of alkali and alkaline earth ion-exchanged zeolites, organic structural directing agent (OSDA) - framework interactions, 
formation mechanisms under hydrothermal/solvothermal synthesis, and adsorption energetics of small molecules, such as water, $\mathrm{CO}_{2}$, and organics, were systematically investigated. ${ }^{24-41}$ The general conclusions are (i) dehydrated zeolites are moderately metastable compared with their dense phase assemblages by less than $15 \mathrm{~kJ} / \mathrm{mol}$ per $\mathrm{TO}_{2}$ unit, and as the framework molar volume increases, such energetic difference tends to be more significant. The energetic stability of dehydrated alkali and alkaline earth ion-exchanged aluminosilicate zeolites is a complex function of $\mathrm{Si} / \mathrm{Al}$ ratio and charge-balancing cations. (ii) Generally, hydration or adsorption of small organics is exothermic and tends to be less negative as the adsorbate loading increases. (iii) Similarly, the energetics of OSDA - framework interactions and zeolite formation energetics under hydrothermal condition suggest moderately exothermic bonding, a product of subtly balanced enthalpy and entropy factors. ${ }^{24-41}$ These studies have laid a solid foundation for zeolite thermodynamics by enabling reliable thermochemical data on natural zeolites of geochemical importance and synthetic pure zeolites applied in the petrochemical industry as sorbents, ion-exchange media and catalysts. Nevertheless, thermodynamics of zeolites with encapsulated heterocore TM species, such as TMO, TMC and/or TMN clusters, has not been systematically investigated and documented. Determination of the macroscopic thermodynamic parameters that govern the formation, stability and microscopic local structures of heterocore TM species under zeolite encapsulation will lead to enhanced understanding of their design, synthesis and applications in chemical engineering processes.

Recently, we reported an adsorption calorimetry study elucidating the real-time formation energetics in regeneration and thermal stability of copper oxo clusters $\left(\mathrm{CuO}_{\mathrm{x}}\right)$ confined within copper-mordenite $(\mathrm{Cu}-\mathrm{MOR})$, a promising low-temperature methane $\left(\mathrm{CH}_{4}\right)$ conversion catalyst, in which a rich energetic landscape is projected for zeolites with different heterocore TM species encapsulated. ${ }^{42}$ The results also suggest that, unlike the extra-framework cations in alkali and alkaline earth ion-exchanged zeolites, once encapsulated, TMO species, such as $\mathrm{CuO}_{\mathrm{x}}$, may alter the oxidation states of metal, stoichiometry and/or phases to achieve energetically favorable final states. The objective of this study is to determine the formation energetics and guest - host interactions, and to identify the relationships among structure, distribution, and energetics of the unique molybdenum (Mo) oxide - zeolite $\mathrm{Y}\left(\mathrm{MoO}_{3} / \mathrm{FAU}\right)$ guest-host systems, in which a $\mathrm{TMO}, \mathrm{MoO}_{3}$, is encapsulated within the microporosity of zeolite $\mathrm{Y}$ with faujasite topology (FAU). FAU is chosen for its compositional tunability, high crystallinity, and open supercage, which enables nano-scale internal space to host $\mathrm{MoO}_{3}$ clusters/particles. Taking advantage of a full spectrum of calorimetric capabilities in the Alexandra Navrotsky Institute for Experimental Thermodynamics (AlexInstitute) at Washington State University (WSU), we probed the enthalpies of formation and energetics of guest - host interactions employing high temperature oxide melt solution calorimetry as the major experimental tool. Coupled with inductively coupled plasma mass spectrometry (ICP-MS), ex situ X-ray diffraction (XRD), transmission electron microscopy (TEM), ex situ diffuse reflectance infrared Fourier transform spectroscopy (DRIFTS), Raman spectroscopy, and thermal analysis using an integrated thermogravimetry - differential scanning calorimetry - mass spectrometry system (TG-DSC-MS), we elucidated the thermodynamics complexity of $\mathrm{MoO}_{3}$ formation under zeolite $\mathrm{Y}$ confinement as a function of $\mathrm{Si} / \mathrm{Al}$ ratio with complimentary compositional, morphological, structural, and spectroscopic insights. Further, the relations among closely balanced compositional, structural, and thermodynamic factors were discussed.

\section{Experimental Methods}

\section{Material Synthesis}

Commercial zeolite $\mathrm{NH}_{4} \mathrm{Y}$ samples (Alfa Aesar) with different $\mathrm{Si} / \mathrm{Al}$ ratios were used as the starting framework materials, which were calcined at $500{ }^{\circ} \mathrm{C}$ for 4 hours to obtain zeolite $\mathrm{HY}$ with faujasite (FAU) topology. Ammonium molybdate tetrahydrate (Sigma-Aldrich, 99\%), the Mo precursor, was introduced into zeolite Y samples by incipient wetness impregnation (IWI). We intentionally kept the $\mathrm{MoO}_{3}$ loading low to minimize crystal growth on the external surface of FAU. Specifically, the zeolites were pretreated in a vacuum oven at $80{ }^{\circ} \mathrm{C}$ for 4 hours. Subsequently, $1.5 \mathrm{~mL}$ ammonium molybdate aqueous solution $(0.05 \mathrm{~mol} / \mathrm{L})$ was dripped onto 1 gram of pretreated samples, followed by 1 hour sonication at room temperature. After oven-drying at $120{ }^{\circ} \mathrm{C}$ overnight and calcination in a tube furnace at $600{ }^{\circ} \mathrm{C}$ in air for 10 hours, the $\mathrm{MoO}_{3} / \mathrm{FAU}$ samples 
were obtained. According to the $\mathrm{Si} / \mathrm{Al}$ ratio $(n)$ and $\mathrm{MoO}_{3}$ encapsulation, the samples are labeled as $n$ FAU and $\mathrm{MoO}_{3} / n$ FAU (see Table 1). For example, the $\mathrm{MoO}_{3}$-containing zeolite $\mathrm{Y}$ sample with $\mathrm{Si} / \mathrm{Al}=3.0$ is named as $\mathrm{MoO}_{3} / 3.0 \mathrm{FAU}$.

\section{Phase and Morphology Identification}

Room temperature ex situ powder X-ray diffraction (XRD) was employed for phase identification using a Rigaku Miniflex 600 diffractometer operated at $40 \mathrm{kV}$ and $15 \mathrm{~mA}$ with $\mathrm{Cu} K a$ radiation $(\lambda=1.5406$ $\AA)$. The XRD patterns were recorded from 5 to $60^{\circ}$ at a step of $2^{\circ}$ per min. The sample morphology was evaluated with transmission electron microscopy (TEM, FEI Tecnai T20, LaB 6 cathode, $200 \mathrm{kV}$ ) in the Franceschi Microscopy and Imaging Center at WSU. In each TEM experiment, a small amount of specimen was dispersed in ethanol under ultrasonication. This suspension was dropped on a carbon-coated nickel grid (200-mesh) and was further dried using infrared lamp for 20 mins.

\section{$\mathrm{N}_{2}$ Adsorption - Desorption Full Isotherm Analysis}

Brunauer-Emmett-Teller (BET) surface area and pore dimension analyses were performed via $\mathrm{N}_{2}$ adsorption - desorption full isotherm analysis at liquid nitrogen temperature $\left(77 \mathrm{~K}\right.$ or $\left.-196{ }^{\circ} \mathrm{C}\right)$ using a commercial gas adsorption analyzer (Micromeritics 3Flex). Each sample was degassed at $300{ }^{\circ} \mathrm{C}$ at the analysis port for at least 5 hours before isotherm measurement.

\section{Compositional and Thermal Analyses}

The sample compositions were determined with ICP-MS (Agilent 770) and an integrated TG-DSC-MS system (Netzsch STA 449 F5 Jupiter coupled with QMS 403 D Aëolos). In the thermal analysis, the sample was placed in a Pt crucible for TG-DSC measurement from 30 to $1000{ }^{\circ} \mathrm{C}$ at $10{ }^{\circ} \mathrm{C} / \mathrm{min}$ under $\mathrm{N}_{2}$ flow of $50 \mathrm{~mL} / \mathrm{min}$. The gas phase product species evolved from TG-DSC were introduced to the MS via a heated capillary tube accurately controlled at $200{ }^{\circ} \mathrm{C}$ for compositional identification. We also calculated the enthalpy of dehydration of each sample based on its TG-DSC-MS data. Dehydration and phase transition are mirrored on the TG-DSC-MS curves (see Table S1).

\section{Ex situ Diffuse Reflectance Infrared Fourier Transform Spectroscopy (DRIFTS)}

Ex situ diffuse reflectance infrared Fourier transform spectroscopy (DRIFTS) experiments were performed on a Nicolet iS50 FT-IR instrument from Thermo Scientific. All samples were pretreated in a $120{ }^{\circ} \mathrm{C}$ oven for 4 hours to remove physi-sorbed water before DRIFTS experiments, which were performed at room temperature with data recorded from 4000 to $650 \mathrm{~cm}^{-1}$.

\section{Raman Spectroscopy}

Raman spectra of all samples were collected on a Horiba LabRAM HR Raman spectrometer with Ventus LP $532 \mathrm{~nm}$ laser. In each measurement, ${ }^{15} \mathrm{mg}$ sample was loaded into a Linkam CCR cell and the spectra were directly recorded at room temperature.

\section{Hydrogen Temperature-Programmed Reduction ( $\left.\mathrm{H}_{2} \mathrm{TPR}\right)$}

Hydrogen temperature-programmed reduction $\left(\mathrm{H}_{2}\right.$ TPR) experiments were carried out on a Diablo 5000A real-time gas analyzer with an Agilent 5975C MSD as the detector. Prior to the $\mathrm{H}_{2} \mathrm{TPR}$ analysis, each sample was pretreated in situ by heating to $600{ }^{\circ} \mathrm{C}\left(10^{\circ} \mathrm{C} / \mathrm{min}\right)$ in argon (Ar) flow $(50 \mathrm{~mL} / \mathrm{min})$. The sample was kept at $600{ }^{\circ} \mathrm{C}$ for half an hour to remove any pre-adsorbed species. Upon cooling to $50{ }^{\circ} \mathrm{C}, \mathrm{H}_{2}$ flow $(25 \mathrm{~mL} / \mathrm{min})$ was introduced, meanwhile the Ar flowrate is adjusted to $25 \mathrm{~mL} / \mathrm{min}$. Subsequently, the sample analyzed was heated from 50 to $850{ }^{\circ} \mathrm{C}$ in 80 minutes in the $1: 1$ mixture of $\mathrm{H}_{2}$ and $\mathrm{Ar}(25 \mathrm{~mL} / 25$ $\mathrm{mL})$. The water signal was recorded for further interpretation.

\section{High Temperature Oxide Melt Drop Solution Calorimetry}

A Tian-Calvet twin microcalorimeter (Setaram Alexsys-1000) at WSU was employed for high temperature oxide melt drop solution calorimetry. The details of this methodology have been reported earlier elsewhere 
by Navrotsky et. al. ${ }^{43}$ To measure the enthalpy of dissolution of each sample, a sample pellet ( $\left.\sim 5 \mathrm{mg}\right)$ was directly dropped into Alexsys-1000, which contains the solvent, lead borate $\left(2 \mathrm{PbO} \cdot \mathrm{B}_{2} \mathrm{O}_{3}\right)$ molten salt at 700 ${ }^{\circ} \mathrm{C}$ under flowing compressed air at a rate of $120 \mathrm{~mL} / \mathrm{min}$. Such calorimetric measurement on each sample was repeated for at least six times. The calorimeter calibration was carried out by measuring the heat content of corundum $\left(\mathrm{Al}_{2} \mathrm{O}_{3}\right)$. The enthalpies of formation and Mo oxide - zeolite Y guest - host interactions of all samples were derived using the thermodynamic cycle listed in Table 2. The errors are calculated as two standard deviations of the mean.

Table 1. Chemical composition, molecular weight and lattice parameter of each FAU or $\mathrm{MoO}_{3} / \mathrm{FAU}$ sample studied on $\mathrm{TO}_{2}$ basis.

\begin{tabular}{|c|c|c|c|c|c|}
\hline Sample & Chemical Composition on $\mathrm{TO}_{2}$ Basis & MW & $a(\AA)$ & BET Surface Area $\left(\mathrm{m}^{2 /} \mathrm{g}\right)$ & Spe \\
\hline 2.9FAU & $\left(\mathrm{SiO}_{2}\right)_{0.742}\left(\mathrm{Al}_{2} \mathrm{O}_{3}\right)_{0.13} \cdot 0.916 \mathrm{H}_{2} \mathrm{O}$ & 74.23 & 8.2906 & 1067.4 & 0.65 \\
\hline 16.1FAU & $\left(\mathrm{SiO}_{2}\right)_{0.942}\left(\mathrm{Al}_{2} \mathrm{O}_{3}\right)_{0.03} \cdot 0.196 \mathrm{H}_{2} \mathrm{O}$ & 63.07 & 8.0297 & 1176.4 & 0.79 \\
\hline 29.3FAU & $\left(\mathrm{SiO}_{2}\right)_{0.967}\left(\mathrm{Al}_{2} \mathrm{O}_{3}\right)_{0.017} \cdot 0.136 \mathrm{H}_{2} \mathrm{O}$ & 62.23 & 8.0424 & 1203.9 & 0.72 \\
\hline $45.6 \mathrm{FAU}$ & $\left(\mathrm{SiO}_{2}\right)_{0.979}\left(\mathrm{Al}_{2} \mathrm{O}_{3}\right)_{0.011} \cdot 0.078 \mathrm{H}_{2} \mathrm{O}$ & 61.28 & 8.145 & 911.1 & 0.58 \\
\hline $\mathrm{MoO}_{3} / 2.9 \mathrm{FAU}$ & $\left(\mathrm{MoO}_{3}\right)_{0.025}\left(\mathrm{SiO}_{2}\right)_{0.742}\left(\mathrm{Al}_{2} \mathrm{O}_{3}\right)_{0.13} \cdot 0.727 \mathrm{H}_{2} \mathrm{O}$ & 74.37 & 8.1581 & 703.1 & 0.44 \\
\hline $\mathrm{MoO}_{3} / 16.1 \mathrm{FAU}$ & $\left(\mathrm{MoO}_{3}\right)_{0.031}\left(\mathrm{SiO}_{2}\right)_{0.942}\left(\mathrm{Al}_{2} \mathrm{O}_{3}\right)_{0.03} \cdot 0.177 \mathrm{H}_{2} \mathrm{O}$ & 67.24 & 7.9671 & 631.6 & 0.46 \\
\hline $\mathrm{MoO}_{3} / 29.3 \mathrm{FAU}$ & $\left(\mathrm{MoO}_{3}\right)_{0.027}\left(\mathrm{SiO}_{2}\right)_{0.967}\left(\mathrm{Al}_{2} \mathrm{O}_{3}\right)_{0.017} \cdot 0.138 \mathrm{H}_{2} \mathrm{O}$ & 66.15 & 8.0297 & 1057.2 & 0.65 \\
\hline $\mathrm{MoO}_{3} / 45.6 \mathrm{FAU}$ & $\left(\mathrm{MoO}_{3}\right)_{0.027}\left(\mathrm{SiO}_{2}\right)_{0.979}\left(\mathrm{Al}_{2} \mathrm{O}_{3}\right)_{0.011} \cdot 0.120 \mathrm{H}_{2} \mathrm{O}$ & 65.91 & 8.0424 & 631.6 & 0.43 \\
\hline
\end{tabular}
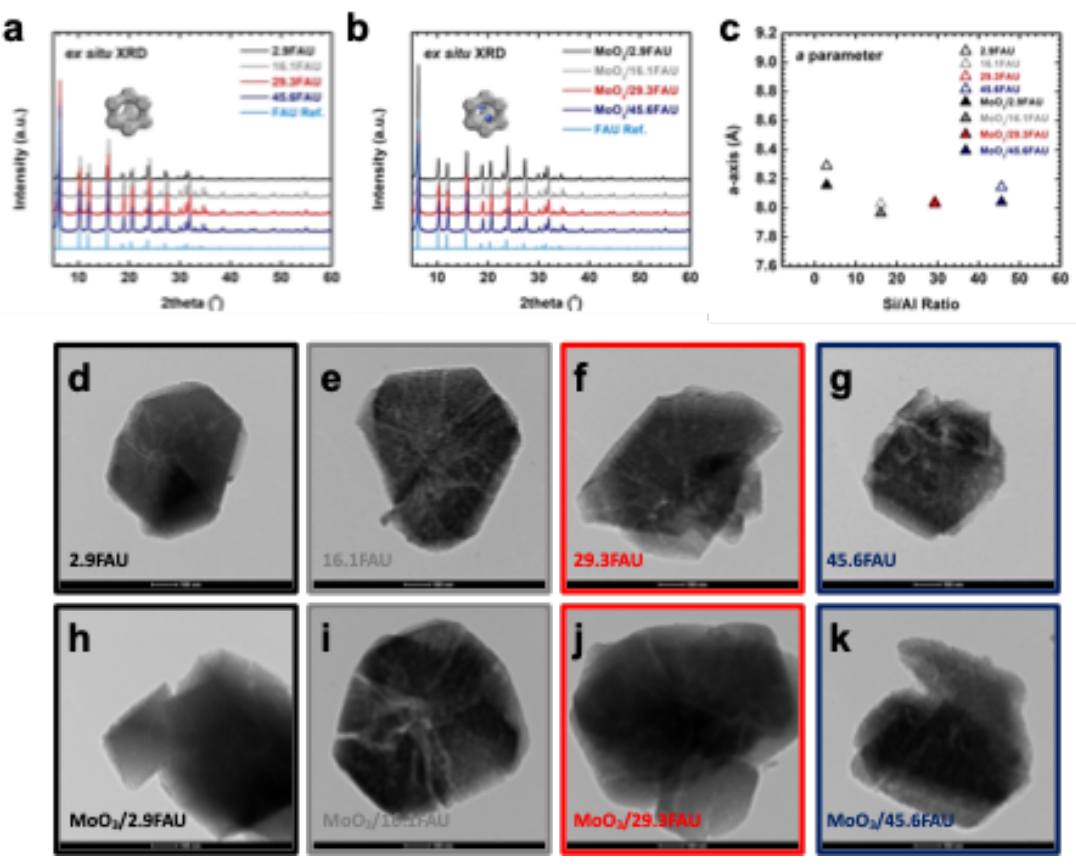

Figure 1. Structural illustration and ex situ XRD patterns of (a) zeolite Y with a faujasite-type structure (FAU) and (b) $\mathrm{MoO}_{3} / \mathrm{FAU}$, and (c) the a parameter of each sample as a function of Si/Al ratio. All XRD patterns were collected at room temperature. The reference patterns of FAU are also included. $(\mathbf{d}-\mathbf{k})$ The TEM images of all samples. The scale bar of each TEM image is $100 \mathrm{~nm}$. 


\section{Results and Discussion}

The compositions determined by coupled ICP-MS and TG-DSC-MS, including the formula and molecular weight of each sample on $\mathrm{TO}_{2}$ (tetrahedron unit) basis, are summarized in Table 1. The compositional results of $\mathrm{MoO}_{3} / \mathrm{FAU}$ suggest successful inclusion of $\mathrm{MoO}_{3}$, and decreased water contents and molecular weight as $\mathrm{Si} / \mathrm{Al}$ increases (see Table 1). The Mo/Al ratio of $2.9 \mathrm{FAU}$, sample with the highest $\mathrm{Al}$ content, is about 0.1 , and the $\mathrm{Mo} / \mathrm{Al}$ ratio of $45.6 \mathrm{FAU}$, sample with the lowest $\mathrm{Al}$ content, is $\sim 1.2$. The ex situ XRD patterns of all FAU and $\mathrm{MoO}_{3} / \mathrm{FAU}$ samples collected at room temperature are shown in Figure 1a and b. The XRD results confirm that all FAU samples have cubic faujasite structure belonging to the Fd3m space group, and $\mathrm{MoO}_{3}$ encapsulation does not lead to significant disturbance of the long-range order of the frameworks. ${ }^{44,45}$ The lattice parameter a of each sample is calculated and listed in Table $\mathbf{1}$ (also see Figure 1c). For both $\mathrm{FAU}$ and $\mathrm{MoO}_{3} / \mathrm{FAU}$, as the $\mathrm{Si} / \mathrm{Al}$ ratio content increases, the a parameter tends to decrease until reaching a plateau at about $8 \AA$. Meanwhile, $\mathrm{MoO}_{3}$ loading results in slightly decreased a parameter by $\sim 1 \%$ (Figure 1c). This set of structural evidence suggests that encapsulation of $\mathrm{MoO}_{3}$ clusters does not result in significant modification or interruption on the framework structure of zeolite $\mathrm{Y}$ over a wide $\mathrm{Si} / \mathrm{Al}$ range. Additionally, our results also indicate that standard XRD cannot detect the encapsulated subnano-sized $\mathrm{MoO}_{3}$ clusters, evidenced by the absence of any detectable diffraction patterns of $\mathrm{MoO}_{3}$.

The TEM images of all samples are assembled in Figure 1d-k. All FAU samples feature octahedral configuration with sharp edged-crystal-like morphology. ${ }^{46,47}$ It appears that the particle size of zeolite $\mathrm{Y}$ in our study, spanning from 400 to $600 \mathrm{~nm}$. Owing to the high thermal stability of FAU, after impregnation with Mo precursor and calcination at $600{ }^{\circ} \mathrm{C}$ for 10 hours, there is no significant morphological degradation detected on all $\mathrm{MoO}_{3} / \mathrm{FAU}$ samples. Interconnected nano-sized channels are clearly observed within these FAU crystals, which remain very well preserved after $\mathrm{MoO}_{3}$ encapsulation. We also noticed that the samples with higher $\mathrm{Si}$ content than that of 2.9FAU tend to feature more interconnected nanochannels. Moreover, according to the TEM images, there is no observable $\mathrm{MoO}_{3}$ particle on the external surface of FAU with $\mathrm{MoO}_{3}$-encapsulated. This is a strong evidence suggesting that the $\mathrm{MoO}_{3}$ particles/clusters are dispersed within the FAU frameworks. Thus, integrating the compositional, structural and morphological results, we conclude that the majority of the population of $\mathrm{MoO}_{3}$ clusters introduced are successfully encapsulated within the crystalline framework and nanoscale porosity of each FAU sample.
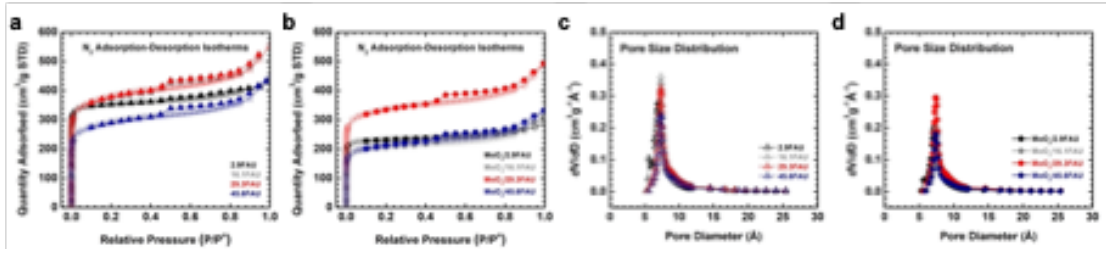

Figure 2. $\mathrm{N}_{2}$ adsorption - desorption isotherms of (a) FAU and (b) $\mathrm{MoO}_{3} / \mathrm{FAU}$ measured at $77 \mathrm{~K}$ (-196 ${ }^{\circ} \mathrm{C}$ ), and corresponding pore size distribution plots of (c) FAU and (d) $\mathrm{MoO}_{3} / \mathrm{FAU}$.

The $\mathrm{N}_{2}$ adsorption - desorption isotherms of all samples are plotted in Figure $\mathbf{2 a}$ and $\mathbf{b}$. The BET specific surface areas are 1067.4, 1176.4, 1203.9 and $911.1 \mathrm{~m}^{2} / \mathrm{g}$ for 2.9FAU, 16.1FAU, 29.3FAU and 45.6FAU, respectively. Generally, $\mathrm{MoO}_{3}$ encapsulation decreases the surface of FAU, and the specific areas are determined to be $703.1 \mathrm{~m}^{2} / \mathrm{g}$ for $\mathrm{MoO}_{3} / 2.9 \mathrm{FAU}, 631.6 \mathrm{~m}^{2} / \mathrm{g}$ for $\mathrm{MoO}_{3} / 16.1 \mathrm{FAU}, 1057.2 \mathrm{~m}^{2} / \mathrm{g}$ for $\mathrm{MoO}_{3} / 29.3 \mathrm{FAU}$, and $631.6 \mathrm{~m}^{2} / \mathrm{g}$ for $\mathrm{MoO}_{3} / 45.6 \mathrm{FAU}$. The pore size distribution plots were presented in Figure $\mathbf{2 c}$ and $\mathbf{d}$. The common behavior is that the pore volume of each FAU sample decreases upon the introduction of $\mathrm{MoO}_{3}$, and the pore size ranges from 0.72 to $0.78 \mathrm{~nm}$ (see Table 1). As demonstrated in the TEM images, there is nano-sized porosity/channel for each FAU or $\mathrm{MoO}_{3} / \mathrm{FAU}$ sample. Inclusion of $\mathrm{MoO}_{3}$ does not lead to significant channel blockage, and there is no detectable bulk $\mathrm{MoO}_{3}$ formation on the external surface of 
zeolite Y (see Figure 1 and $\mathbf{2}$ ).

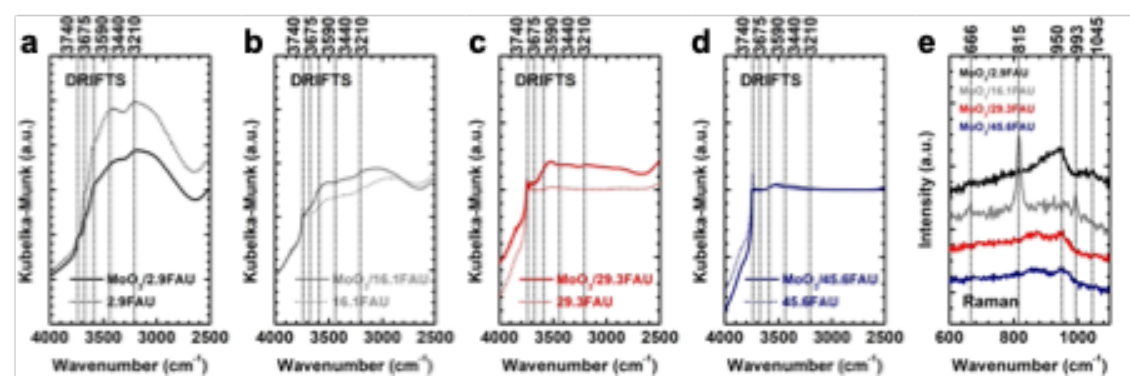

Figure 3. (a-d) Ex situ DRIFTS data of all FAU and $\mathrm{MoO}_{3} / \mathrm{FAU}$ samples. The sample names are labeled in each figure, and (e) Raman spectroscopy results of $\mathrm{MoO}_{3} / \mathrm{FAU}$.

The interfacial chemistry and $\mathrm{MoO}_{3}-\mathrm{FAU}$ bonding specifics of all samples were studied by ex situ DRIFTS (see Figure 3a-d). Fundamentally, the low wavenumber absorbance of bonds within $\mathrm{MoO}_{3}$ appears to be weak. Si/Al ratio increase leads to decreased local hydrophilicity within zeolite Y, evidenced by clearly observed intensity decrease in peaks between 3700 and $3000 \mathrm{~cm}^{-1}$, and at $1640 \mathrm{~cm}^{-1}$, corresponding to the stretching vibration of $\mathrm{O}-\mathrm{H}$ groups and bending vibration of $\mathrm{H}_{2} \mathrm{O}$ molecules, respectively. ${ }^{42,48,49}$ More specifically, for 2.9FAU, $\mathrm{MoO}_{3}$ encapsulation results in decreased intensity of peaks at $3640 \mathrm{~cm}^{-1}$ (shoulder) and $3545 \mathrm{~cm}^{-1}$ (shoulder) both ascribed to the stretching vibration of $\mathrm{O}-\mathrm{H}$ bond of $^{\mathrm{H}} \mathrm{H}_{2} \mathrm{O}$ adsorbed at the Brønsted acid sites, and absorbance at 3440 (broad) $\mathrm{cm}^{-1}$ and $3210 \mathrm{~cm}^{-1}$ (broad) which are assigned to hydroxyl groups of water clusters, whereas the intensity of peak at $3740 \mathrm{~cm}^{-1}$ corresponding to stretching vibration of isolated silanol (Si-OH) groups does not change (Figure 3a). ${ }^{50,51}$ In contrast, for the other FAU samples, the isolated silanol peak at $3740 \mathrm{~cm}^{-1}$ decreases upon $\mathrm{MoO}_{3}$ introduction. In other words, the $\mathrm{MoO}_{3}$ clusters on 2.9FAU are very likely anchored or encapsulated at the Brønsted acid sites near $\mathrm{Al}^{3+}$. In contrast, for FAU samples with higher $\mathrm{Si}$ contents equal or higher than $\mathrm{Si} / \mathrm{Al}=16.1, \mathrm{MoO}_{3}$ tends to interact with a full spectrum of energetically distinctive sites closed to $\mathrm{Si}$ atoms because of low $\mathrm{Al}^{3+}$ concentration. Indeed, such selective binding of $\mathrm{MoO}_{3}$ at or near $\mathrm{Al}^{3+}$ sites was also reported for encapsulation of $\mathrm{MoO}_{3}$ in zeolites with other topologies and $\mathrm{Si} / \mathrm{Al}$ ratios, such as ZSM-5. ${ }^{50,51}$ Hence, evidence from DRIFTS suggests the presence of well-dispersed $\mathrm{MoO}_{3}$ particles bonded near Al-OH in 2.9FAU, the sample with higher $\mathrm{Al}$ content and crystallinity (see Figure 1a), while for high silica FAU samples it is likely that there are multiple $\mathrm{MoO}_{3}$ species experiencing intricate local chemistry with a spectrum of silanol groups and the pore structures. More specifically, when the zeolite is Al-rich, such as the sample 2.9FAU, Brønsted acid sites dominate the binding, reflected by the decrease of absorbance intensity at 3640 and $3545 \mathrm{~cm}^{-1}$, corresponding to bridged hydroxyl groups (Brønsted acid sites) located at the supercage and sodalite cages, respectively. ${ }^{52,53}$ On the other hand, the distribution of $\mathrm{MoO}_{3}$ binding sites on Si-rich zeolites is more complicated with much higher heterogeneity. For example, K. Tsutsumi et. al. employed energy level function derived from experimental heat function to investigate the surface heterogeneity of zeolite NaY. ${ }^{54}$ Their study suggested there were at least five types of silanol sites on zeolite NaY. ${ }^{54}$ Parallelly, Hattori et. al. studied the silanol groups on dealuminated high silica MFI zeolite, in which they proposed four types of silanols: isolated silanol, terminal silanols, including geminal and vicinal silanol, and silanol nest. ${ }^{55}$ Moreover, Carlos et. al. employed density functional theory (DFT) method to understand the silanol chemistry of aluminum-substituted MFI nanosheets. ${ }^{56}$ They proposed two additional types of silanols: (i) silanols with silicon directly bonds aluminum through non-protonated oxygen, and (ii) silanols whose silicon connected to the aluminum via protonated oxygen. ${ }^{56}$ Therefore, it is clear that the bonding distribution of $\mathrm{MoO}_{3}$ on high silica zeolites is much more complex compared with its chemistry on zeolites rich in aluminum.

The Raman spectroscopy results are presented in Figure 3e, which further confirm the conclusion based on DRIFTS data by presenting a set of peaks reflecting the degree of dispersion and symmetry for $\mathrm{MoO}_{3}$ 
particles. The weak single Raman band at ${ }^{\sim} 993 \mathrm{~cm}^{-1}$, seen on all $\mathrm{MoO}_{3} / \mathrm{FAU}$ samples, is attributed to the $\mathrm{Mo}=\mathrm{O}$ stretching. ${ }^{57}$ The presence of a broad shoulder band at about $950 \mathrm{~cm}^{-1}$ for each $\mathrm{MoO}_{3} / \mathrm{FAU}$ suggests that there are well-dispersed $\mathrm{MoO}_{3}$ species at the vacancy defects of FAU framework. ${ }^{57}$ Interestingly, for $\mathrm{MoO}_{3} / 16.1 \mathrm{FAU}$, well-resolved bands at 815 , and $666 \mathrm{~cm}^{-1}$ were observed, which indicate the existence of nano-sized crystalline particles in addition to well-dispersed $\alpha-\mathrm{MoO}_{3} .{ }^{57-60}$ Such particles around $1 \mathrm{~nm}$ are commonly seen for zeolites with 12-member rings and nano-channels, such as FAU, which features supercage and nano-scale porosity. ${ }^{57-60}$ Since there is no observable large $\mathrm{MoO}_{3}$ particles residing on the external surface of all samples, majority of $\mathrm{MoO}_{3}$ nanoparticles are considered to be hosted in the internal space, crystalline framework and/or nano-channels, of FAU. Meanwhile, we also found evidence suggesting the presence of $-\mathrm{Al}_{2}\left(\mathrm{MoO}_{4}\right)_{3}$ clusters in $\mathrm{MoO}_{3} / 2.9 \mathrm{FAU}$, the sample with the highest $\mathrm{Al}$ content, according to a weak band barely resolved at about $1045 \mathrm{~cm}^{-1}$. ${ }^{57,58,60}$ However, such $-\mathrm{Al}_{2}\left(\mathrm{MoO}_{4}\right)_{3}$ clusters or smaller particles were not detected on other $\mathrm{MoO}_{3} / \mathrm{FAU}$ samples with higher Si content. This phenomenon highlights the strong $\mathrm{MoO}_{3}-\mathrm{FAU}$ interactions with defined interfacial bonding at the $\mathrm{Al}$ atoms of $\mathrm{AlO}_{4}$ tetrahedra. In general, the Raman spectroscopy results synchronize well with the DRIFTS data, both suggesting dispersed $\mathrm{MoO}_{3}$ nanoparticles encapsulated in the FAU frameworks. The $\mathrm{MoO}_{3}-\mathrm{FAU}$ interfacial bonding specifics, degree of dispersion and symmetry for encapsulated $\mathrm{MoO}_{3}$ particles depend on the $\mathrm{Si} / \mathrm{Al}$ ratio.
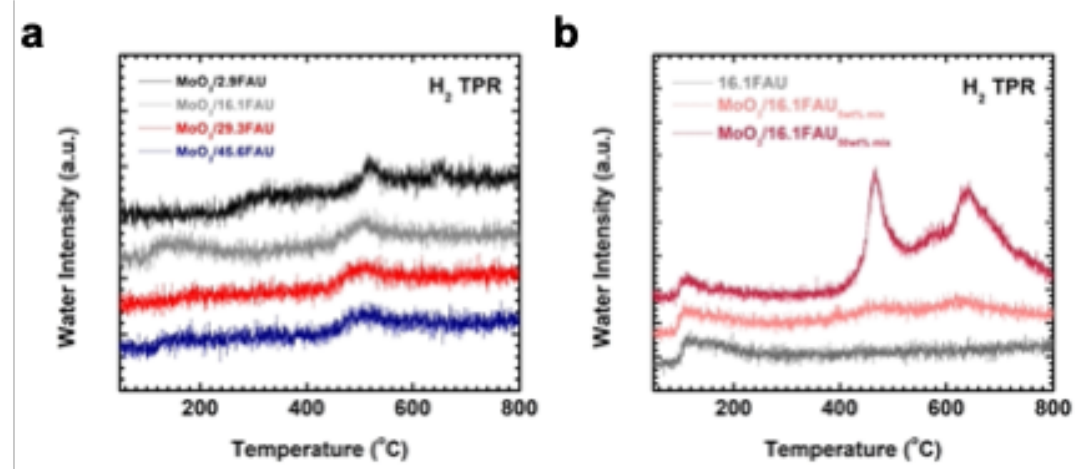

Figure 4. $\mathrm{H}_{2}$ TPR results of (a) $\mathrm{MoO}_{3} / \mathrm{FAU}$ samples, and (b) control experiments on pure 16.1FAU, physical mixture of bulk $\mathrm{MoO}_{3}$ and 16.1FAU with Mo content of 5 and 50 Mo-wt\%.

To reveal the influence of $\mathrm{Si} / \mathrm{Al}$ ratio on the oxygen donation capability of encapsulated $\mathrm{MoO}_{3}$ species, $\mathrm{MoO}_{3}$ dispersion, and $\mathrm{MoO}_{3}$ - zeolite $\mathrm{Y}$ interactions, $\mathrm{H}_{2}$ TPR experiments were carried out on all $\mathrm{MoO}_{3} / \mathrm{FAU}$ samples, in which the signal of reduction product, $\mathrm{H}_{2} \mathrm{O}$, was simultaneously monitored as a function of temperature (see Figure 4a). Generally, weak TPR signals were seen on all $\mathrm{MoO}_{3} / \mathrm{FAU}$ samples. To validate that these broad peaks are due to reduction of the little amount of encapsulated $\mathrm{MoO}_{3}$ species, we performed three TPR control experiments with the same program on (i) pure 16.1FAU, (ii) physical mixture of bulk $\mathrm{MoO}_{3}$ and 16.1FAU with $5 \mathrm{Mo}-\mathrm{wt} \%$, and (iii) physical mixture of bulk $\mathrm{MoO}_{3}$ and $16.1 \mathrm{FAU}$ with Mo content of 50 Mo-wt\%. In Figure $\mathbf{4 b}$, for each control sample, the water peak at about $100{ }^{\circ} \mathrm{C}$ is owing to low temperature dehydration of the FAU framework. The well-resolved MS signals peaked at 470 and 640 ${ }^{\circ} \mathrm{C}$, not seen on pure $16.1 \mathrm{FAU}$, are due to stepwise reduction of molybdenum trioxide, from $\mathrm{MoO}_{3}$ to $\mathrm{MoO}_{2}$ and subsequent reduction from $\mathrm{MoO}_{2}$ to Mo metal. ${ }^{61-63}$ We also noticed that as the $\mathrm{MoO}_{3}$ content decreases from 50 to $5 \mathrm{Mo}-\mathrm{wt} \%$, the intensities of these two peaks significantly decrease. The peaks have comparable intensities as those of $\mathrm{MoO}_{3} / 16.1 \mathrm{FAU}$, and are stronger than those of pure 16.1FAU. The results of the TPR control experiments are strong evidence confirming the weak TPR signals observed on $\mathrm{MoO}_{3} / \mathrm{FAU}$ samples in Figure 4a are not simply noise. Specifically, there is a main reduction peak on all $\mathrm{MoO}_{3} / \mathrm{FAU}$ samples studied spanning from 440 to $550{ }^{\circ} \mathrm{C}$. Typically, this $\mathrm{H}_{2} \mathrm{O}$ peak is considered to be the product of serial $\mathrm{MoO}_{3}$ reduction in $\mathrm{H}_{2}$ flow forming $\mathrm{MoO}_{2}$ and $\mathrm{H}_{2} \mathrm{O} .{ }^{61-63}$ In addition, the slight "baseline shift" observed 
at temperatures higher than $525{ }^{\circ} \mathrm{C}$ probably indicates gradual further reduction of $\mathrm{MoO}_{2}$ species. We also noticed that as the $\mathrm{Si} / \mathrm{Al}$ increases the reduction temperature of $\mathrm{MoO}_{3}$ gently shifts to lower temperature. For $\mathrm{MoO}_{3} / 2.9 \mathrm{FAU}$, the reduction peak centers at $\sim 520^{\circ} \mathrm{C}$, while the other $\mathrm{MoO}_{3} / \mathrm{FAU}$ samples have peaks at lower temperatures, $504{ }^{\circ} \mathrm{C}$ for $\mathrm{MoO}_{3} / 16.1 \mathrm{FAU}, 502^{\circ} \mathrm{C}$ for $\mathrm{MoO}_{3} / 29.3 \mathrm{FAU}$, and $500{ }^{\circ} \mathrm{C}$ for $\mathrm{MoO}_{3} / 45.6 \mathrm{FAU}$. Besides, the water peaks appear to be widening as $\mathrm{Si} / \mathrm{Al}$ increases, implying broader $\mathrm{MoO}_{3}$ nanoparticles distribution on high silica FAU samples, which is consistent with the Raman spectroscopy data. These phenomena indicate that as the framework $\mathrm{Al}$ content increases, the $\mathrm{MoO}_{3}$ clusters are energetically better stabilized by the FAU framework, leading to higher reduction resistance and evidenced by the increased onset reduction temperature. In other words, the magnitudes of $\mathrm{MoO}_{3}$ - zeolite $\mathrm{Y}$ interactions impact the onset reduction temperature of $\mathrm{MoO}_{3}$ species. ${ }^{61,62}$ The energetics of $\mathrm{MoO}_{3}$ encapsulation in all FAU frameworks is the topic we'll discuss in the final section of this paper. Indeed, similar phenomena were also reported for $\mathrm{MoO}_{3}$ supported on zeolites with other topologies and $\mathrm{Si} / \mathrm{Al}$ ratios. ${ }^{63}$ We hesitate to quantify the $\mathrm{MoO}_{3}$ loading using $\mathrm{H}_{2}$ TPR because of the low signal to noise ratio seen in Figure 4a.
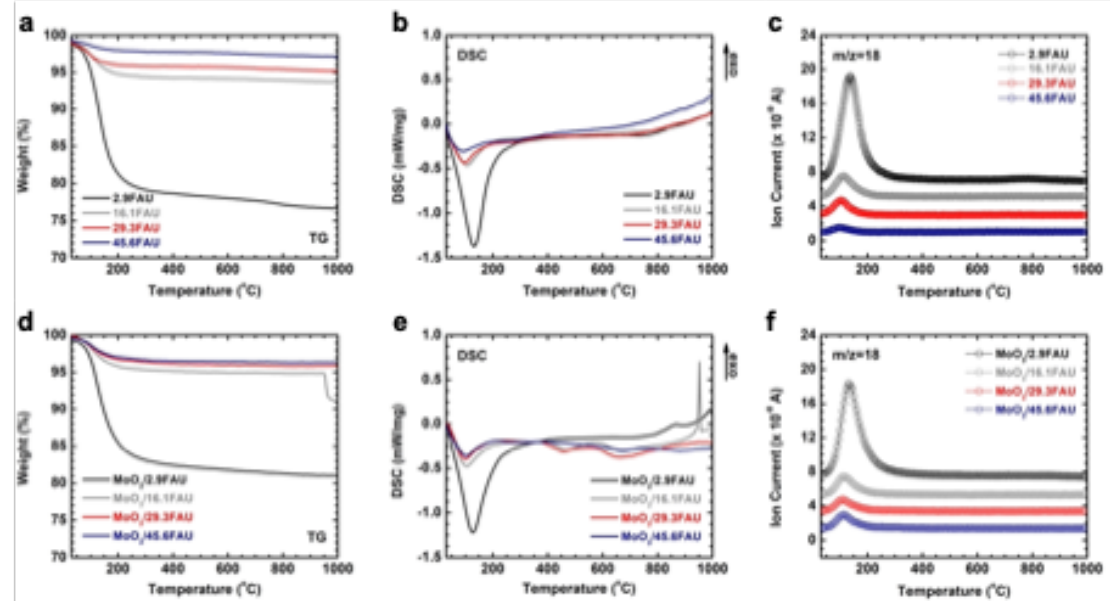

Figure 5. The thermal analysis results of FAU (a) TG, (b) DSC, and (c) MS (m/z=18); and $\mathrm{MoO}_{3} / \mathrm{FAU}$ (d) TG, (e) DSC, and (f) MS (m/z=18) with $\mathrm{N}_{2}$ flow at $50 \mathrm{~mL} / \mathrm{min}$ from 30 to $1000{ }^{\circ} \mathrm{C}$.

The TG-DSC-MS thermal analysis results are plotted in Figure 5. The DTG and DDSC data are presented in Figure 6 and 7. Each sample features a single-step dehydration followed by calorimetric events that do not lead to observable weight loss. Specifically, the TG-DSC-MS results of FAU are relatively straightforward (Figure 5a-c, and $\mathbf{6 a}$ and $\mathbf{c}$ ). All FAU samples present a single stage weight loss due to dehydration centered at about $145{ }^{\circ} \mathrm{C}$, after which the TG-DSC-MS, DTG and DDSC profiles are nearly featureless. The total weight losses for FAU samples range from $20.3 \%$ for $2.9 \mathrm{FAU}$ to $1.7 \%$ for $45.6 \mathrm{FAU}$, decreasing as the $\mathrm{Si} / \mathrm{Al}$ or hydrophobicity increases. Based on the DSC peak areas and corresponding weight loss the directly calculated dehydration enthalpies from DSC are endothermic, $67.9 \pm 2.1 \mathrm{~kJ} / \mathrm{mol} \mathrm{H}_{2} \mathrm{O}$ for $2.9 \mathrm{FAU}, 97.0 \pm$ $0.8 \mathrm{~kJ} / \mathrm{mol} \mathrm{H} \mathrm{O}_{2} \mathrm{O}$ for $16.1 \mathrm{FAU}, 109.8 \pm 3.9 \mathrm{~kJ} / \mathrm{mol} \mathrm{H}_{2} \mathrm{O}$ for $29.3 \mathrm{FAU}$, and $176.1 \pm 4.0$ for $45.6 \mathrm{FAU}$. According to the XRD patterns in Figure 8a, all post-analysis FAU samples maintain their framework structure, with 2.9FAU exhibiting noticeable partial degradation. 

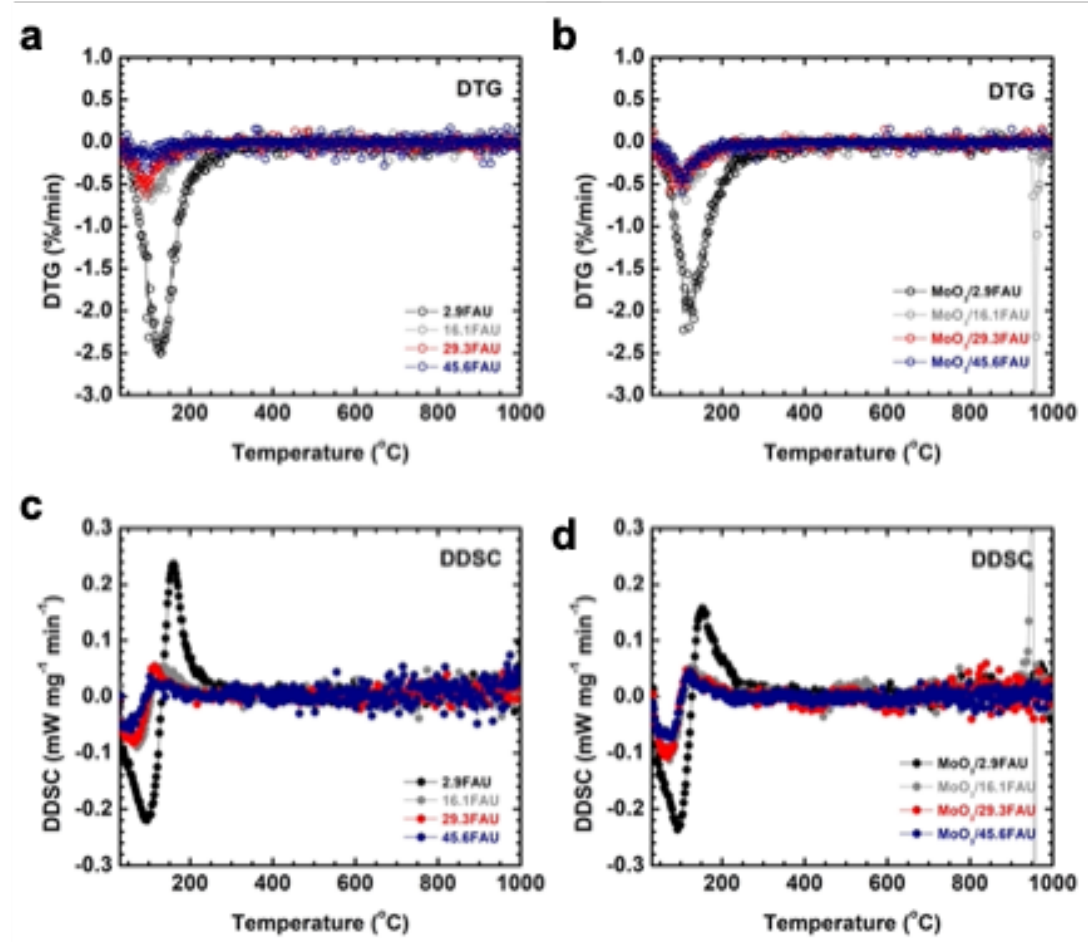

Figure 6. The derivative TG (DTG) profiles of (a) FAU and (b) $\mathrm{MoO}_{3} / \mathrm{FAU}$; and derivative DSC (DDSC) results of (c) FAU and (d) $\mathrm{MoO}_{3} / \mathrm{FAU}$ with $\mathrm{N}_{2}$ flow at $50 \mathrm{~mL} / \mathrm{min}$ from 30 to $1000{ }^{\circ} \mathrm{C}$.
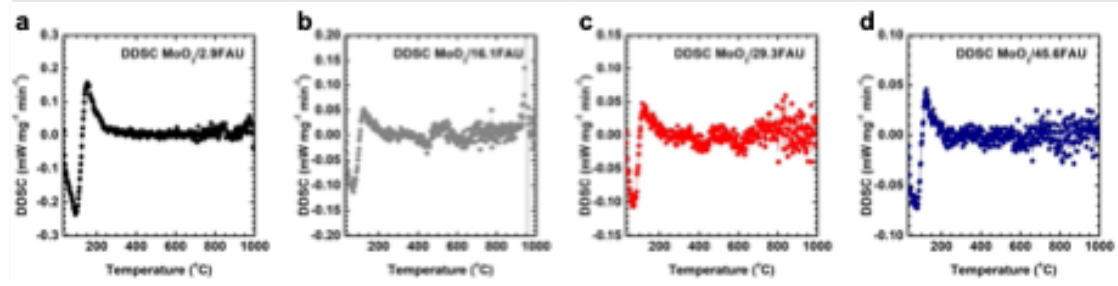

Figure 7. The highlighted derivative DSC (DDSC) profiles of $\mathrm{MoO}_{3} / \mathrm{FAU}$ with $\mathrm{N}_{2}$ flow at $50 \mathrm{~mL} / \mathrm{min}$ from 30 to $1000{ }^{\circ} \mathrm{C}$, (a) $\mathrm{MoO}_{3} / 2.9 \mathrm{FAU}$, (b) $\mathrm{MoO}_{3} / 16.1 \mathrm{FAU}$, (a) $\mathrm{MoO}_{3} / 29.3 \mathrm{FAU}$, and (d) $\mathrm{MoO}_{3} / 45.6 \mathrm{FAU}$.
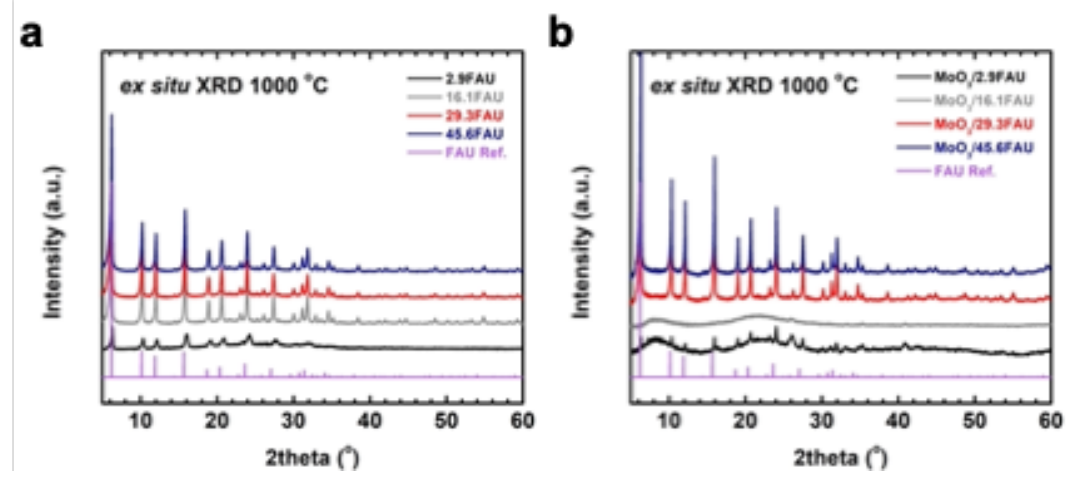
Figure 8. Ex situ XRD patterns of (a) FAU, and (b) $\mathrm{MoO}_{3} / \mathrm{FAU}$ treated at $1000{ }^{\circ} \mathrm{C}$ in $\mathrm{N}_{2}$ flow at 50 $\mathrm{mL} / \mathrm{min}$. The reference patterns of FAU are included.

For all $\mathrm{MoO}_{3} / \mathrm{FAU}$ samples dehydration, concluded at temperatures below $300{ }^{\circ} \mathrm{C}$, is responsible for major weight loss. The desorbed water is $17.3 \%$ for $\mathrm{MoO}_{3} / 2.9 \mathrm{FAU}, 4.5 \%$ for $\mathrm{MoO}_{3} / 16.1 \mathrm{FAU}, 3.7 \%$ for $\mathrm{MoO}_{3} / 29.3 \mathrm{FAU}$, and $3.2 \%$ for $\mathrm{MoO}_{3} / 45.6 \mathrm{FAU}$ (see Figure 5d and $\mathbf{6 b}$ ). According to the TG-DSC traces, the directly calculated enthalpies of dehydration from DSC are $75.6 \pm 3.8 \mathrm{~kJ} / \mathrm{mol} \mathrm{H}_{2} \mathrm{O}$ for $\mathrm{MoO}_{3} / 2.9 \mathrm{FAU}$, $107.9 \pm 1.7 \mathrm{~kJ} / \mathrm{mol} \mathrm{H} \mathrm{O}_{2}$ for $\mathrm{MoO}_{3} / 16.1 \mathrm{FAU}, 99.4 \pm 2.9 \mathrm{~kJ} / \mathrm{mol} \mathrm{H}_{2} \mathrm{O}$ for $\mathrm{MoO}_{3} / 29.3 \mathrm{FAU}$, and $98.5 \pm 3.9$ $\mathrm{kJ} / \mathrm{mol} \mathrm{H}_{2} \mathrm{O}$ for $\mathrm{MoO}_{3} / 45.6 \mathrm{FAU}$. Moreover, the dehydration enthalpies here were directly calculated by integrating the DSC curve of each sample, from zeolite-adsorbed and confined water to water vapor at elevated temperature in DSC. Such calculation introduces significantly more endothermic heat effects to the dehydration enthalpies. Thus, we applied a thermochemical cycle (see Table S1) to correct the dehydration enthalpies to be at $25^{\circ} \mathrm{C}$. The corrected dehydration enthalpies $\left(\Delta H_{\text {del, }, 1}\right)$ range from $14.9 \pm 2.1 \mathrm{~kJ} / \mathrm{mol}$ water for $2.9 \mathrm{FAU}$ to $88.9 \pm 4.0 \mathrm{~kJ} / \mathrm{mol}$ water for $45.6 \mathrm{FAU}$, and from $19.3 \pm 3.9 \mathrm{~kJ} / \mathrm{mol}$ water for $\mathrm{MoO}_{3} / 45.6 \mathrm{FAU}$ to $38.9 \pm 1.7 \mathrm{~kJ} / \mathrm{mol}$ water for $\mathrm{MoO}_{3} / 16.1 \mathrm{FAU}$. Moreover, in principle, the enthalpy of dehydration is the average of all heat effects for water removal from a unit molar of sample with a unit of "kJ/mol water". The nanoscale porosity of Al-rich zeolites can hold substantial amount of pore-confined water. These water molecules are space-fillers that are liquid-like in zeolites with hydrophilic frameworks, and do not directly bind the surface groups of zeolites. In contrast, although the internal surfaces of Si-rich zeolites are mostly hydrophobic, which adsorb much less amount of water. Most of these water molecules directly bind the surface hydroxyls of zeolites. Therefore, the dehydration enthalpies of FAU and $\mathrm{MoO}_{3} / \mathrm{FAU}$ with higher $\mathrm{Si} / \mathrm{Al}$ ratios appear to be more endothermic than those of Al-rich FAU, which confine large water clusters filling the pores. In addition, it is also such confinement-related "averaging effect" leads to comparable dehydration enthalpies for FAU and $\mathrm{MoO}_{3} / \mathrm{FAU}$ with the same $\mathrm{Si} / \mathrm{Al}$ ratio. Indeed, similar phenomena of (de)hydration energetics have been observed by Navrotsky et. al. in multiple studies on zeolites, particularly, on ion-exchanged zeolites with multivalent cations, where the (de)hydration enthalpy is not a clear function of $\mathrm{Si} / \mathrm{Al}$ ratio. ${ }^{26}, 31,38,39,43$ They also figured out that (de)hydration enthalpy is tightly related to the degree of hydration and other guest species like cations and small organics. ${ }^{26,31,38,39,43}$

Interestingly, although there is no significant weight loss on the TG profiles from 300 to $900{ }^{\circ} \mathrm{C}$ for all samples, a pair of broad endothermic calorimetric peaks is observed centered at about 450 and $645^{\circ} \mathrm{C}$ on the DSC curves of $\mathrm{MoO}_{3} / 16.1 \mathrm{FAU}, \mathrm{MoO}_{3} / 29.3 \mathrm{FAU}$, and $\mathrm{MoO}_{3} / 45.6 \mathrm{FAU}$, consistent with the $\mathrm{MoO}_{3}$ thermal reduction temperatures under $\mathrm{H}_{2}$ TPR conditions (Figure 4, 5e and 6d). We noticed that although these two peaks appear to be poorly resolved on the DSC curves of $\mathrm{MoO}_{3} / 45.6 \mathrm{FAU}$, the DDSC traces clearly reveal their trends (see Figure 6 and 7). Nevertheless, without the presence of any detectable volatile thermal reduction products evidenced by MS, such as water $(\mathrm{m} / \mathrm{z}=18)$ or $\mathrm{O}_{2}(\mathrm{~m} / \mathrm{z}=32)$, we hesitate to conclude that the pair of DSC signals originate from stagewise thermal reduction of $\mathrm{MoO}_{3}$ in nonoxidative environments (see Figure 5 and S1). ${ }^{42,64}$ In this case, we argue that, from a thermodynamic perspective, it is possible that the endothermic peak at ${ }^{\sim} 450{ }^{\circ} \mathrm{C}$ may be due to short-range structural transition of Mo species to reach the local assemblages with the lowest energetic states. ${ }^{65,66}$ On the other hand, considering the melting point of bulk $\mathrm{MoO}_{3}\left(802{ }^{\circ} \mathrm{C}\right)$ and "melting point depression" - a common phenomenon seen for confined solid-state guest materials, we deduce, it is also possible that the second endothermic DSC peak at about $645{ }^{\circ} \mathrm{C}$ could be attributed to melting of encapsulated subnano $\mathrm{MoO}_{3} .{ }^{35}, 67$ We have documented similar decreased solid - liquid phase transition temperature in an earlier study on confinement of organic solid in mesoporous silicas with different pore dimensions. ${ }^{35}$ Additionally, we also noticed that the endothermic DSC peak at $\sim 450{ }^{\circ} \mathrm{C}$ appears to be absent for $\mathrm{MoO}_{3} / 2.9 \mathrm{FAU}$. We attribute that it is probably because the strong $\mathrm{MoO}_{3}$ - framework interactions on Al-rich 2.9FAU thermodynamically hinder the unfavorable redox or local structural transition of encapsulated $\mathrm{MoO}_{3}$. Surprisingly, a sharp exothermic peak is observed on the DSC curve of $\mathrm{MoO}_{3} / 16.1 \mathrm{FAU}$ at about $930{ }^{\circ} \mathrm{C}$, associated with significant weight loss as much as $4.0 \%$. Based on the ex situ XRD patterns in Figure $\mathbf{8 b}$, suggesting completely amorphous phase for $\mathrm{MoO}_{3} / 16.1 \mathrm{FAU}$ after this exothermic peak, we conclude that after melting, the Mo species evaporate, 
and escape zeolite Y confinement leading to eventual collapse of the framework structure, which is highly exothermic. The coexistence of exothermic DSC peak and significant weight loss reflecting vaporization of Mo species indicates the strong $\mathrm{MoO}_{3}$ - zeolite $\mathrm{Y}$ guest - host interactions. For $\mathrm{MoO}_{3} / 2.9 \mathrm{FAU}$, the slightly exothermic calorimetric peak at about $875^{\circ} \mathrm{C}$ is indicative of partial phase degradation of zeolite $\mathrm{Y}$, confirmed by the XRD patterns of post DSC analysis sample (see Figure $8 \mathbf{b}$ ), suggesting $\mathrm{MoO}_{3} / 2.9 \mathrm{FAU}$ is partially amorphized. Such intricate guest - host interactions between TMO clusters and zeolites were also seen in our study on $\mathrm{Cu}$ oxo cluster $\left(\mathrm{CuO}_{\mathrm{x}}\right)$ encapsulated in $\mathrm{MOR}$, a low-temperature methane conversion catalyst, in which thermal decomposition of $\mathrm{CuO}_{\mathrm{x}}$ were recorded at about $915{ }^{\circ} \mathrm{C}$, liberating molecular oxygen, resulting in a similar weak exothermic DSC peak, and leading to amorphized MOR framework. ${ }^{42}$

Table 2. Thermochemical cycle to calculate the enthalpies of formation $\left(\right.$ per $\left.\mathrm{TO}_{2}\right)$ at $25{ }^{\circ} \mathrm{C}$ of $\mathrm{FAU}$ and $\mathrm{MoO}_{3} / \mathrm{FAU}$ samples from their constituent oxides and elements.

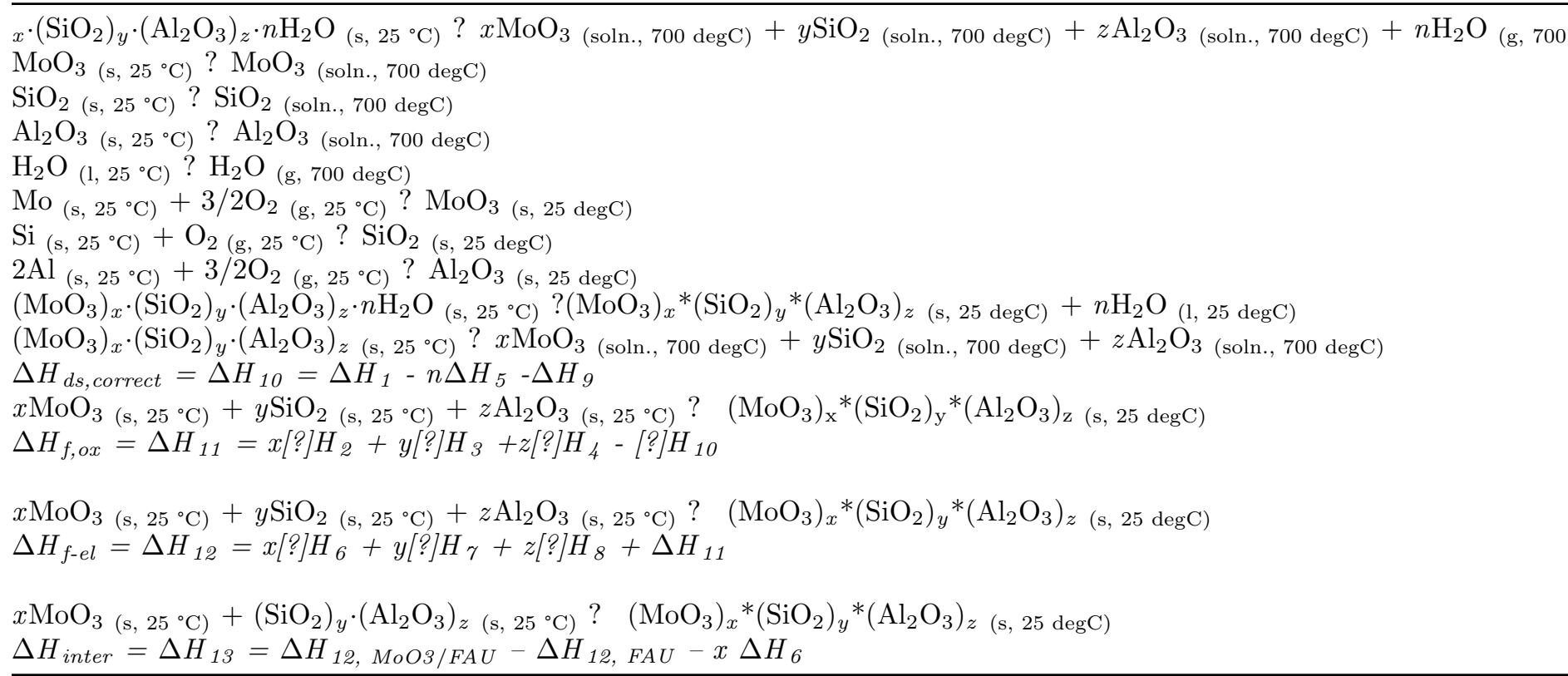

Table 3. Enthalpies of drop solution for constituent oxides and water in molten lead borate at $700{ }^{\circ} \mathrm{C}$ and their enthalpies of formation from elements at $25{ }^{\circ} \mathrm{C}$.

\begin{tabular}{lll}
\hline Oxide & $\boldsymbol{\Delta H}_{\text {ds }}(\mathrm{kJ} / \mathbf{m o l})$ & $\boldsymbol{\Delta} \boldsymbol{H}_{\text {f,el }}(\mathbf{k J} / \mathbf{m o l})$ \\
Corundum $\left(\mathrm{Al}_{2} \mathrm{O}_{3}\right)$ & $107.4 \pm 0.2^{43}$ & $-1675.7 \pm 1.3^{67}$ \\
Molybdenum trioxide $\left(\mathrm{MoO}_{3}\right)$ & $-17.8 \pm 0.4^{\text {this work }}$ & $-745.2 \pm 0.4^{67}$ \\
Quartz $\left(\mathrm{SiO}_{2}\right)$ & $39.4 \pm 0.4^{43}$ & $-910.7 \pm 1.0^{67}$ \\
Water $\left(\mathrm{H}_{2} \mathrm{O}\right)$ & $68.9 \pm 0.1^{67}$ & $-285.8 \pm 0.1^{67}$ \\
\hline
\end{tabular}

Table 4. Enthalpies of drop solution $\left(\Delta H_{\mathrm{ds}}\right)$ and formation enthalpies from oxides $\left(\Delta H_{\mathrm{f}, \mathrm{ox}}\right)$ and elements $\left(\Delta H_{\mathrm{f}, \mathrm{el}}\right)$ at $25{ }^{\circ} \mathrm{C}$ (per $\left.\mathrm{TO}_{2}\right)$ of all samples. The dehydration enthalpies of each sample relative to liquid water $\left(\Delta H_{\text {deh,l }}\right)$ and enthalpies of interactions $\left(\Delta H_{\text {inter }}\right)$ are also listed. 


\begin{tabular}{|c|c|c|c|c|c|}
\hline Sample & $\Delta H_{\mathrm{ds}}(\mathrm{kJ} / \mathrm{mol})$ & $\Delta H_{\mathrm{f}, \mathrm{ox}}(\mathrm{kJ} / \mathrm{mol})$ & $\Delta H_{\mathrm{f}, \mathrm{el}}(\mathrm{kJ} / \mathrm{mol})$ & $\Delta H_{\mathrm{deh}, \mathrm{l}}\left(\mathrm{kJ} / \mathrm{mol} \mathrm{H}_{2} \mathrm{O}\right)$ & $\Delta \boldsymbol{H}_{\text {inter }}$ \\
\hline $2.9 \mathrm{FAU}$ & $50.3 \pm 4.0$ & $69.7 \pm 4.1$ & $-822.1 \pm 2.0$ & $14.9 \pm 2.1$ & $\mathrm{~N} / \mathrm{A}$ \\
\hline 16.1FAU & $19.0 \pm 0.3$ & $40.8 \pm 0.3$ & $-865.7 \pm 0.2$ & $30.9 \pm 0.8$ & $\mathrm{~N} / \mathrm{A}$ \\
\hline 29.3FAU & $13.6 \pm 0.8$ & $40.8 \pm 0.8$ & $-867.5 \pm 0.4$ & $37.7 \pm 3.9$ & $\mathrm{~N} / \mathrm{A}$ \\
\hline 45.6FAU & $14.7 \pm 1.1$ & $32.8 \pm 1.1$ & $-871.9 \pm 0.8$ & $88.9 \pm 4.0$ & $\mathrm{~N} / \mathrm{A}$ \\
\hline $\mathrm{MoO}_{3} / 2.9 \mathrm{FAU}$ & $47.2 \pm 1.7$ & $61.1 \pm 1.8$ & $-849.1 \pm 1.0$ & $21.3 \pm 3.8$ & $-334.3 \pm$ \\
\hline $\mathrm{MoO}_{3} / 16.1 \mathrm{FAU}$ & $20.8 \pm 1.2$ & $38.0 \pm 1.2$ & $-891.8 \pm 0.6$ & $38.9 \pm 1.7$ & $-95.7 \pm 7.5$ \\
\hline $\mathrm{MoO}_{3} / 29.3 \mathrm{FAU}$ & $18.2 \pm 0.5$ & $34.3 \pm 0.5$ & $-897.8 \pm 0.3$ & $26.4 \pm 2.9$ & $-242.8 \pm 4$ \\
\hline $\mathrm{MoO}_{3} / 45.6 \mathrm{FAU}$ & $17.0 \pm 1.4$ & $32.8 \pm 1.4$ & $-896.3 \pm 0.7$ & $19.3 \pm 3.9$ & $-159.8 \pm 15$ \\
\hline
\end{tabular}

High temperature oxide melt drop solution calorimetry, which can be used to measure the heat content of the sample plus its heat of dissolution and/or any other reactions at the temperature of solvent hosted in the calorimeter, is a powerful methodology to determine the formation enthalpies of solid-state materials at room temperature. ${ }^{43,69,70,71}$ More specifically, in this study, the sample pellet, about $5 \mathrm{mg}$, was dropped from ambient condition at room temperature into the molten salt solvent (lead borate, $2 \mathrm{PbO} \cdot \mathrm{B}_{2} \mathrm{O}_{3}$ ) kept in a twin Calvet-type calorimeter (Setaram Alexsys-1000) at high temperature $\left(700{ }^{\circ} \mathrm{C}\right)$ under air flow $(120 \mathrm{~mL} / \mathrm{min})$. The subtle difference in temperature caused by dropping, temperature increase, and phase transition, reaction and/or dissolution in the solvent is detected by the thermopiles, monitored by the computer program, and converted to real heat output reflecting heat of drop solution by a calibration factor predetermined. ${ }^{71}$ Using appropriate thermochemical cycles, the differences in heats of drop solution are derived representing the enthalpies of reaction or formation at room temperature. ${ }^{43,69,70,71}$ For example, the enthalpies of formation for all FAU and $\mathrm{MoO}_{3} / \mathrm{FAU}$ samples from constituent oxides $\left(\Delta H_{\mathrm{f}, \mathrm{ox}}\right.$ in Table 2$)$ and elements $\left(\Delta H_{\mathrm{f}, \mathrm{el}}\right.$ in Table 2) at $25{ }^{\circ} \mathrm{C}$ are determined from their heats of drop solution, $\Delta H_{\mathrm{ds}}$ or $\Delta H_{1}$ in Table 2, with the thermodynamic cycle detailed in Table 2. The $\Delta H_{\mathrm{ds}}$ and $\Delta H_{\mathrm{f}, \mathrm{el}}$ of all constituent oxides are referenced from previous reports (see Table 3). ${ }^{43,68}$

The $\Delta H_{\mathrm{ds}}$ in molten lead borate at $700{ }^{\circ} \mathrm{C}$ and their enthalpies of formation from oxides $\left(\Delta H_{\mathrm{f}, \mathrm{ox}}\right)$ and elements $\left(\Delta H_{\mathrm{f}, \mathrm{el}}\right)$ at $25{ }^{\circ} \mathrm{C}$ are listed in Table 4 . We corrected the energetic effects of dehydration to be at 25 ${ }^{\circ} \mathrm{C}\left(\Delta H_{\text {deh,l }}\right)$ using dehydration enthalpies obtained from thermal analyses. $\Delta H_{\mathrm{f}, \mathrm{ox}}$ is plotted as a function of $\mathrm{Si} / \mathrm{Al}$ ratio in Figure 9. In general, the measured heats of drop solution $\left(\Delta H_{\mathrm{ds}}\right)$ are all endothermic, spanning from $50.3 \pm 4.0 \mathrm{~kJ} / \mathrm{mol}$ per $\mathrm{TO}_{2}(2.9 \mathrm{FAU})$ to $13.6 \pm 0.8 \mathrm{~kJ} / \mathrm{mol}$ per $\mathrm{TO}_{2}(29.3 \mathrm{FAU})$ for $\mathrm{FAU}$, and from $47.2 \pm 1.7 \mathrm{~kJ} / \mathrm{mol}$ per $\mathrm{TO}_{2}\left(\mathrm{MoO}_{3} / 2.9 \mathrm{FAU}\right)$ to $13.6 \pm 0.8 \mathrm{~kJ} / \mathrm{mol}$ per $\mathrm{TO}_{2}\left(\mathrm{MoO}_{3} / 45.6 \mathrm{FAU}\right)$ for $\mathrm{MoO}_{3} / \mathrm{FAU}$ samples. The common trend is that (i) increase in $\mathrm{Si} / \mathrm{Al}$ ratio results in decreasing endothermic $\Delta H_{\mathrm{ds}}$ until reaching $\sim 15 \mathrm{~kJ} / \mathrm{mol}$ per $\mathrm{TO}_{2}$; (ii) $\mathrm{MoO}_{3}$ encapsulation does not significantly impacts the magnitude of $\Delta H_{\mathrm{ds}}$. Overall, the $\Delta H_{\mathrm{f}, \mathrm{ox}}$ of pure FAU frameworks are endothermic, ranging from 69.7 $\pm 4.1 \mathrm{~kJ} / \mathrm{mol}$ per $\mathrm{TO}_{2}$ for $2.9 \mathrm{FAU}$, to $32.8 \pm 1.1 \mathrm{~kJ} / \mathrm{mol}$ per $\mathrm{TO}_{2}$ for $45.6 \mathrm{FAU}$. Positive $\Delta H_{\mathrm{f}, \mathrm{ox}}$ values suggest the FAU samples are energetically less stable compared with their dense phase assemblages from constituent oxides, $\mathrm{Al}_{2} \mathrm{O}_{3}, \mathrm{SiO}_{2}$ and water. As the $\mathrm{Si} / \mathrm{Al}$ ratio increases, $\Delta H_{\mathrm{f}, \mathrm{ox}}$ of $\mathrm{FAU}$ framework becomes less endothermic, exhibiting an exponential trend which gradually levels until reaching about $30 \mathrm{~kJ} / \mathrm{mol}$ per $\mathrm{TO}_{2}$ (see Figure 9). This trend is consistent with the formation thermodynamics of homogeneous acid base ternary oxide, as seen in earlier studies on various ion-exchanged zeolites. ${ }^{25,26,31,37-39}$ Considering that the samples we used are zeolite HY (FAU), the increased degree of metastability as Al content increases is mainly because of $\mathrm{Al}^{3+}$ substitution, which results in formation of negatively charged $\mathrm{AlO}_{4}{ }^{-}$tetrahedra and increased framework charge density. In Figure 9, we plotted the formation enthalpies data of a family of ion-exchanged zeolite Y (FAU) with the same $\mathrm{Si} / \mathrm{Al}$ ratio ( $\mathrm{Si} / \mathrm{Al} \sim 2.8$ ) reported by Yang and Navrotsky, in which they systematically evaluated the impacts of extra-framework cations on formation enthalpies of zeolite Y. ${ }^{31}$ Therefore, FAU becomes energetically less stable from constituent oxides at $25{ }^{\circ} \mathrm{C}$ as the $\mathrm{Al}$ content or the average ionic potential increases. 


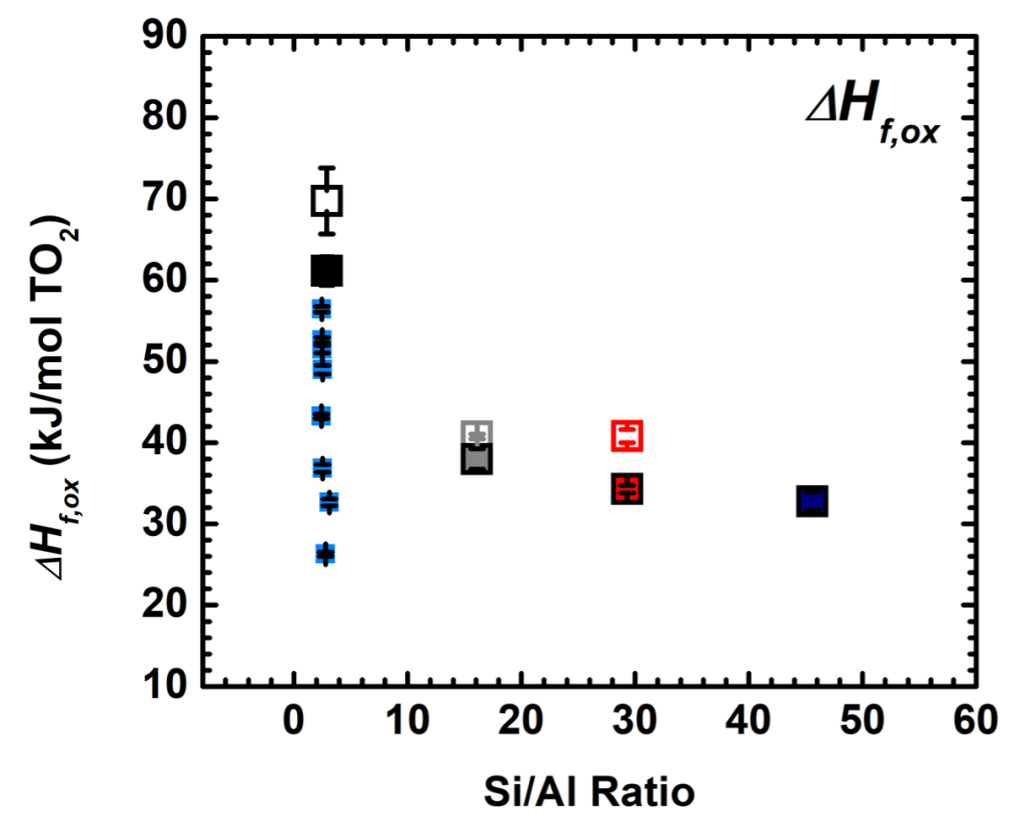

Figure 9. Enthalpies of formation from constituent oxides $\left(\mathrm{SiO}_{2}, \mathrm{Al}_{2} \mathrm{O}_{3}\right.$ and $\left.\mathrm{MoO}_{3}\right)$ at $25{ }^{\circ} \mathrm{C}\left(\right.$ per $\left.\mathrm{TO}_{2}\right)$ of all FAU and $\mathrm{MoO}_{3} / \mathrm{FAU}$ samples. Enthalpies of formation data of ion-exchanged zeolite $\mathrm{Y}$ with the same $\mathrm{Si} / \mathrm{Al}$ ratio $(\mathrm{Si} / \mathrm{Al} \sim 2.8)$ documented by Yang and Navrotsky in 2000 are also presented (light blue squares). 31

On the other hand, encapsulation of $\mathrm{MoO}_{3}$ energetically stabilizes FAU framework, supported by the less endothermic formation enthalpy of each $\mathrm{MoO}_{3} / \mathrm{FAU}$ compared with corresponding FAU, ranging from $61.1 \pm$ $1.8 \mathrm{~kJ} / \mathrm{mol}$ per $\mathrm{TO}_{2}$ for $\mathrm{MoO}_{3} / 2.9 \mathrm{FAU}$ to $32.8 \pm 1.4 \mathrm{~kJ} / \mathrm{mol}$ per $\mathrm{TO}_{2}$ for $\mathrm{MoO}_{3} / 45.6 \mathrm{FAU}$. Parallelly, $\Delta H_{\mathrm{f}, \mathrm{el}}$ mimics the trend of $\Delta H_{\mathrm{f}, \mathrm{ox}}$ (see Table 4). Notably, compared with the magnitudes of OSDA - framework interactions, which are around $5.0 \mathrm{~kJ} / \mathrm{mol}$ per $\mathrm{TO}_{2}$, confinement of $\mathrm{MoO}_{3}$ significantly stabilizes FAU. ${ }^{29}$ In other words, energetically favorable $\mathrm{MoO}_{3}$ particles - FAU framework interactions through surface binding and confinement effects are expected, which pay for the "energetic cost of being small". We calculated the enthalpies of $\mathrm{MoO}_{3}-\mathrm{FAU}$ interactions, $\Delta H_{\text {inter }}$ in $\mathrm{kJ} / \mathrm{mol}$ per $\mathrm{MoO}_{3}$, to quantify the magnitudes of energetic effects of formation of $\mathrm{MoO}_{3} / \mathrm{FAU}$ from bulk $\mathrm{MoO}_{3}$ and pure FAU (see Table 2). All $\Delta H_{\text {inter }}$ values are exothermic between $-95.7 \pm 7.5 \mathrm{~kJ} / \mathrm{mol}$ per $\mathrm{MoO}_{3}$ for $\mathrm{MoO}_{3} / 16.1 \mathrm{FAU}$ and $-334 \pm 102.7 \mathrm{~kJ} / \mathrm{mol}$ per $\mathrm{MoO}_{3}$ for $\mathrm{MoO}_{3} / 2$.9FAU. Despite wide error bar originated from the cumulative errors of our stepwise calculations, the most exothermic $\Delta H_{\text {inter }}$ was observed on $\mathrm{MoO}_{3} / 2.9 \mathrm{FAU}$, which indicates significant energetic cost to stabilize the well-dispersed metastable amorphous $\mathrm{MoO}_{3}$ clusters, while the energetically least favorable interactions were observed for $\mathrm{MoO}_{3} / 16.1 \mathrm{FAU}$, which has nanosized $\mathrm{MoO}_{3}$ particles that probably lower the total energies through exothermic crystallization process as seen in our earlier study on confinement of organic nanocrystals. ${ }^{35}$ Moreover, we would like to mention that the $\Delta H_{\text {inter }}$ is more exothermic than what was observed for confinement of rigid organic molecules in mesoporous silicas. ${ }^{35}$ This is owing to the (i) strong confinement effects applied by the microporosity of zeolite $\mathrm{Y}$, and the (ii) defined $\mathrm{MoO}_{3}-\mathrm{FAU}$ interfacial bonding, evidenced by the DRIFTS and Raman results. Thus, integration of these two types of strong interactions energetically stabilizes the dispersed $\mathrm{MoO}_{3}$ clusters, and is a prerequisite ensuring their activity, selectivity, and stability as the catalytic sites in $\mathrm{CH}_{4}$ carburization to synthesize $\mathrm{C}_{6} \mathrm{H}_{6}$, as demonstrated by Gao et. al. and Zheng et. al. in their kinetic, spectroscopic and computational investigations. ${ }^{50,60}$ 
In sum, this integrated structural, spectroscopic and calorimetric study leads to the following conclusions and implications. First, we argue that hydration thermodynamics is more complex for zeolites with encapsulated oxide particles, involving both compositional, interfacial (functional groups and defects), redox and structural factors. Typically, classic cation - framework - water interplays govern the hydration of alkali, alkaline earth and transition metal ion-exchanged zeolites, in which extra-framework cations, such as $\mathrm{Na}^{+}$ and $\mathrm{Ca}^{2+}$, determine the trend of hydration energetics because they are extremely hydrophilic and readily hydrated. Here, in contrast, after calcination in air at elevated temperature, the negative charges of FAU are neutralized by the strong $\mathrm{MoO}_{3}-\mathrm{FAU}$ interfacial bonding, which also anchors the $\mathrm{MoO}_{3}$ particles. Hence, $\mathrm{MoO}_{3} / \mathrm{FAU}$ does not exhibit substantially different average hydration energetics compared with the corresponding pure FAU sample, although the hydration thermodynamics at near-zero water coverage may be distinctively different between FAU and $\mathrm{MoO}_{3} / \mathrm{FAU}$. Unveiling the interfacial heterogeneity, and potential redox evolutions in hydration of $\mathrm{MoO}_{3} / \mathrm{FAU}$ is an ongoing study in our group at WSU. Secondly, the nature of $\mathrm{MoO}_{3}-\mathrm{FAU}$ interfacial binding significantly differs from the cation-framework interactions in ionexchanged zeolites, which are ionic. Multiple evidences from DRIFTS and Raman spectroscopy suggest when the FAU is Al-rich, $\mathrm{MoO}_{3}$ is primarily anchored at or near the Brønsted acid sites, leading to energetically favorable bonds that feature more ionic characteristics and higher particle dispersion. For high silica FAU, a spectrum of silanol groups would direct formation of $\mathrm{MoO}_{3}$ nanoparticles with broader size distributions via formation of intricate interfacial bonds with more covalent nature. Thus, at a given $\mathrm{MoO}_{3}$ loading, the $\mathrm{Si} / \mathrm{Al}$ ratio of FAU plays a critical role governing the interfacial bonding specifics, particle dispersion, and confinement energetics of the $\mathrm{MoO}_{3} / \mathrm{FAU}$ system. Lastly, the thermal analysis and formation energetics results both suggest that encapsulated TMO particles in zeolites could simultaneously alter the oxidation states of metal, local subnano-assemblages, sizes and types of bonding in the synthesis process to reach the lowest overall energetic states, particularly, for $\mathrm{MoO}_{3}$, an oxide material with multiple phases, redox properties, and relatively low melting point.

\section{Conclusions}

In this study, the thermodynamics of $\mathrm{MoO}_{3}$ encapsulated in zeolite $\mathrm{Y}$ with different $\mathrm{Si} / \mathrm{Al}$ ratios was investigated using calorimetry integrated with spectroscopic and structural methods, in which we elucidated the energetic landscape of $\mathrm{MoO}_{3} / \mathrm{FAU}$ catalysts, redox and phase transitions of subnano $\mathrm{MoO}_{3}$ clusters/particles under zeolite $\mathrm{Y}$ confinement, and the thermodynamics-confinement-dispersion relationships. In sum, the phase transition and particle dispersion of these $\mathrm{MoO}_{3} / \mathrm{FAU}$ catalytic materials are tightly governed by the formation energetics of $\mathrm{MoO}_{3} / \mathrm{FAU}$ and the magnitudes of $\mathrm{MoO}_{3}-\mathrm{FAU}$ interactions, which are functions of $\mathrm{Si} / \mathrm{Al}$ ratio. Documentation of systematic experimental thermodynamic data on zeolite-based heterogeneous catalysts with encapsulated metal, oxides and carbides particles will aid chemical engineers and materials chemists for rational development of advanced catalytic materials using earth-abundant elements for a more sustainable future.

\section{Acknowledgements}

Di Wu thanks Profs. Alexandra Navrotsky, Bruce C. Gates, Stacey I. Zones, Gang-yu Liu, Ricardo H. R. Castro and Roland Faller for their guidance during his Ph.D. education and postdoctoral training. Di Wu also thanks Prof. James N. Petersen and the WSU colleagues for the exceptionally strong support during his junior faculty stage. This work was supported by institutional funds from the Gene and Linda Voiland School of Chemical Engineering and Bioengineering and Alexandra Navrotsky Institute for Experimental Thermodynamics at WSU. Xianghui Zhang was supported by Chambroad Distinguished Scholarship. Cody B. Cockreham received support from the Achievement Rewards for College Scientists (ARCS) Fellowship from the ARCS Seattle Chapter. Hui Sun acknowledges the financial support from the National Natural Science Foundation of China, grant 21878097 and 91634112, and the Natural Science Foundation of Shanghai, grant 21ZR1417700. Xiaofeng Guo acknowledges the support by the institutional funds from the Department of Chemistry and the U.S. Department of Energy, Office of Nuclear Energy, grant DE-NE0008582. Portions of this research were also supported by collaboration, services, and infrastructure through the Nuclear Science Center User Facility at WSU. 


\section{Dedication}

This study is dedicated to a friend and colleague of Di Wu, Prof. Chia-Kuang (Frank) Tsung, Associate Professor of Chemistry at Boston College, who passed away on January 5, 2021 from complications due to COVID-19.

\section{Literature Cited}

1. Serna P, Gates BC. Molecular Metal Catalysts on Supports: Organometallic Chemistry Meets Surface Science. Acc. Chem. Res. 2014; 47 (8): 2612-2620. https://doi.org/10.1021/ar500170k.

2. Guan E, Ciston J, Bare SR, Runnebaum RC, Katz A, Kulkarni A, Kronawitter AX, Gates BC. Supported Metal Pair-Site Catalysts. ACS Catal. 2020; 10 (16): 9065-9085. https://doi.org/10.1021/ acscatal.0c02000.

3. Wang H, Wang L, Xiao F. Metal@Zeolite Hybrid Materials for Catalysis. ACS Cent. Sci. 2020; 6 (10): 1685-1697. https://doi.org/10.1021/acscentsci.0c01130.

4. Grundner S, Markovits M, Li G et. al. Single-site Trinuclear Copper Oxygen Clusters in Mordenite for Selective Conversion of Methane to Methanol. Nat. Comm. 2015; 6: 7546. https://doi.org/10.1038/ ncomms8546.

5. Wang H, Wang L, Lin D et. al. Strong Metal-Support Interactions on Gold Nanoparticle Catalysts Achieved through Le Chatelier's Principle. Nat. Catal. 2021; in press. https://doi.org/10.1038/s41929021-00611-3.

6. Zhang C, Chen C, Dong H, Shen J-R, Dau H, Zhao J. Identification of Molybdenum Oxide Nanostructures on Zeolites for Natural Gas Conversion. Science. 2015; 348 (6235): 686-690. https: //doi.org/10.1126/science.aaa7048.

7. Sushkevich VL, Palagin D, Ranocchiari M, van Bokhoven JA. Selective Anaerobic Oxidation of Methane Enables Direct Synthesis of Methanol. Science. 2017; 356 (6337): 523-527. https://doi.org/10. 1126/science . aam9035.

8. Jin Z, Wang L, Zuidema E, Mondal K, Zhang M, Zhang J, Wang C, Meng X, Yang H, Mesters C, Xiao F. Hydrophobic Zeolite Modification for in situ Peroxide Formation in Methane Oxidation to Methanol. Science. 2020; 367 (6474): 193-197. https://doi.org/10.1126/science.aaw1108.

9. Therrien AJ, Hensley AJR, Marcinkowski MD, Zhang R, Lucci FR, Coughlin B, Schilling AC, McEwen J-S, Sykes ECH. An atomic-scale View of Single-site Pt Catalysis for Low-temperature CO Oxidation. Nat. Catal. 2018; 1: 192-198. https://doi.org/10.1038/s41929-018-0028-2.

10. Jones J, Xiong H, DeLaRiva AT, Peterson EJ, Pham H, Challa SR, Qi G, Oh S, Wiebenga MH, Hernández XIP, Wang Y, Datye A K. Thermally Stable Single-atom Platinum-on-Ceria Catalysts via Atom Trapping. Science. 2020; 353 (6295): 150-154. https://doi.org/10.1126/science . aaf8800.

11. Xiang Y, Kruse N. Tuning the catalytic CO Hydrogenation to Straight-and Long-chain Aldehydes/Alcohols and Olefins/Paraffins. Nat. Commun. 2017; 7: 13058. https://doi.org/10.1038/ ncomms 13058 .

12. Zhang S, Huang ZQ, Ma Y. et. al. Solid Frustrated-Lewis-Pair Catalysts Constructed by Regulations on Surface Defects of Porous Nanorods of $\mathrm{CeO}_{2}$. Nat. Commun. 2017; 8: 15266. https://doi.org/10.1038/ ncomms15266.

13. Yang Z, Li H, Zhou H, Wang L, Wang L, Zhu Q, Xiao J, Meng X, Chen J, and Xiao F. Coking-Resistant Iron Catalyst in Ethane Dehydrogenation Achieved through Siliceous Zeolite Modulation. J. Am. Chem. Soc. 2020; 142 (38): 16429-16436. https://doi.org/10.1021/jacs.0c07792. 
14. Zhu J, Osuga R, Ishikawa R, Shibata N, Ikuhara Y, Kondo JN, Ogura M, Yu J, Wakihara T, Liu Z, Okubo T. Ultrafast Encapsulation of Metal Nanoclusters into MFI Zeolite in the Course of Its Crystallization: Catalytic Application for Propane Dehydrogenation. Angew. Chem. Int. Ed. 2020; 59 (44): 19669-19674. https://doi.org/10.1002/anie.202007044.

15. Iida T, Shetty M, Murugappan K, Wang Z, Ohara K, Wakihara T, Romań-Leshkov Y. Encapsulation of Molybdenum Carbide Nanoclusters inside Zeolite Micropores Enables Synergistic Bifunctional Catalysis for Anisole Hydrodeoxygenation. ACS Catal. 2017; 7 (12): 8147-8151. https://doi.org/10.1021/acscatal . $7 \mathrm{~b} 03175$.

16. Liu, W., You, W., Sun, W. et. al. Ambient-pressure and Low-temperature Upgrading of Lignin Biooil to Hydrocarbons using a Hydrogen Buffer Catalytic System. Nat Energy. 2020; 5: 759-767. https: //doi.org/10.1038/s41560-020-00680-x.

17. Zhang T. Taking on All of the Biomass for Conversion. Science. 2020; 367 (6484): 1305-1306. https://doi.org/10.1126/science. abb1463.

18. Zhang X, Chaudhary N, Hawkins MR et. al. Determining the Hydration Energetics on CarbonSupported Ru Catalysts: An Adsorption Calorimetry and Density Functional Theory Study. Catal. Today 2021; 365 (1): 172-180. https://doi.org/10.1016/j.cattod.2020.09.021.

19. Ding K, Gulec A, Johnson AM et. al. Identification of Active Sites in CO Oxidation and WaterGas Shift over Supported Pt Catalysts. Science. 2015; 350 (6257): 389-393. https://doi.org/10.1126/ science.aac6368.

20. Yao S, Zhang X, Zhou W et. al. Atomic-layered Au Clusters on $\alpha$-MoC as Catalysts for the Lowtemperature Water-Gas Shift Reaction. Science. 2017; 357 (6349): 189-192. https://doi.org/10.1126/ science. aah4321.

21. Navrotsky A, Lilova K, Wu D, Asta M. Thermodynamics of Complex Solids. J. Mater. Res. 2019; 34 (19): 3241-3242. https://doi.org/10.1557/jmr.2019.300.

22. Davis ME, Lobo RF. Zeolite and Molecular Sieve Synthesis. Chem. Mater. 1992; 4 (4): 756-768. https://doi.org/10.1021/cm00022a005.

23. Navrotsky A, Trofymluk O, Levchenko A A. Thermochemistry of Microporous and Mesoporous Materials. Chem. Rev. 2009; 109 (9): 3885-3902. https://doi.org/10.1021/cr800495t.

24. Petrovic I, Navrotsky A, Davis ME, Zones SI. Thermochemical Study of the Stability of Frameworks in High Silica Zeolites. Chem. Mater. 1993; 5 (12): 1805-1813. https://doi.org/10.1021/cm00036a019.

25. Hu Y, Navrotsky A, Chen CY, Davis ME. Thermochemical Study of the Relative Stability of Dense and Microporous Aluminophosphate Frameworks. Chem. Mater. 1995; 7 (10): 1816-1823. https://doi. org/10.1021/cm00058a010.

26. Petrovic I, Navrotsky A. Thermochemistry of Na-Faujasites with Varying Si/Al Ratios. Microporous Mater. 1997; 9 (1-2): 1-12. https://doi.org/10.1016/S0927-6513(96)00060-0.

27. Piccione PM, Laberty C, Yang S, Camblor MA, Navrotsky A, Davis ME. Thermochemistry of Pure-Silica Zeolites. J. Phys. Chem. B. 2000; 104 (43): 10001-10011. https://doi.org/10.1021/jp002148a.

28. Piccione PM, Woodfield BF, Boerio-Goates J, Navrotsky A, Davis ME. Entropy of Pure-Silica Molecular Sieves. J. Phys. Chem. B. 2001; 105 (25): 6025-6030. https://doi.org/10.1021/jp010491p.

29. Piccione PM, Yang S, Navrotsky A, Davis ME. Thermodynamics of Pure-silica Molecular Sieve Synthesis. J. Phys. Chem. B 2002; 106 (14): 3629-3638. https://doi.org/10.1021/jp014427j.

30. Yang S, Navrotsky A, Phillips BL. In Situ Calorimetric, Structural, and Compositional Study of Zeolite Synthesis in the System $5.15 \mathrm{Na}_{2} \mathrm{O}-1.00 \mathrm{Al}_{2} \mathrm{O}_{3}-3.28 \mathrm{SiO}_{2}-165 \mathrm{H}_{2} \mathrm{O}$. J. Phys. Chem. B. 2000; 104 (25): 
6071-6080. https://doi.org/10.1021/jp9944278.

31. Yang S, Navrotsky A. Energetics of Formation and Hydration of Ion-exchanged Zeolite Y. Microporous Mesoporous Mater. 2000; 37 (1-2): 175-186. https://doi.org/10.1016/S1387-1811(99)00264-4.

32. Yang S, Navrotsky A, Wesolowski DJ, Pople JA. Study on Synthesis of TPA-Silicalite-1 from Initially Clear Solutions of Various Base Concentrations by In Situ Calorimetry, Potentiometry, and SAXS. Chem. Mater. 2004; 16 (2): 210-219. https://doi.org/10.1021/cm030587r.

33. Yang S, Navrotsky A. Early-Stage Reactions in Synthesis of TPA-Silicalite-1: Studies by In Situ Calorimetry, SAXS, and pH Measurements. Chem. Mater. 2004; 16 (19): 3682-3687. https://doi.org/ 10.1021/cm035272q.

34. Yang S, Navrotsky A. In Situ Calorimetric Study of the Growth of Silica TPA-MFI Crystals from an Initially Clear Solution. Chem. Mater. 2002; 14 (6): 2803-2811. https://doi.org/10.1021/cm0200689.

35. Wu D, Hwang SJ, Zones SI, Navrotsky A. Guest-Host Interactions of a Rigid Organic Molecule in Porous Silica Frameworks. Proc. Natl. Acad. Sci. USA. 2014; 111 (5): 1720-1725. https://doi.org/10. 1073/pnas. 1323989111.

36. Sun H, Wu D, Guo X, Shen B, Liu J, Navrotsky A. Energetics of Confinement of Hexane in Ca-Na Ion Exchanged Zeolite A. J. Phys. Chem. C 2014; 118 (44): 25590-25596. https://doi.org/10.1021/ jp508514e.

37. Sun H, Wu D, Guo X, Shen B, Navrotsky A. Energetics and Structural Evolution of Na-Ca Exchanged Zeolite A during Heating. Phys. Chem. Chem. Phys. 2015; 17, 9241-9247. https://doi.org/10.1039/ c5cp00016e.

38. Sun H, Wu D, Guo X, Shen B, Navrotsky A. "Energetics of Sodium-Calcium Exchanged Zeolite A", Phys. Chem. Chem. Phys. 2015; 17, 11198-11203. https://doi.org/10.1039/c5cp01133g.

39. Sun H, Wu D, Liu K, Guo X, Navrotsky A. Energetics of Alkali and Alkaline Earth Ion-exchanged Zeolite A. J. Phys. Chem. C 2016; 120 (28): 15251-15256. https://doi.org/10.1021/acs.jpcc.6b04840.

40. Yang S, Guo X, Verma A, Shiflett MB, Corbin DR, Navrotsky A. Thermochemical Insights into Stability and Hydration of Ion-Exchanged Zeolite ZK-5 (KFI Framework). J. Phys. Chem. C. 2020; 124 (48): 26193-26202. https://doi.org/10.1021/acs.jpcc.0c06796.

41. Zones SI. Jayanthi K, Pascual J, Xie D, Navrotsky A. Energetics of the Local Environment of StructureDirecting Agents Influence Zeolite Synthesis. Chem. Mater. 2021; 33 (6) 2126-2138. https://doi.org/ 10.1021/acs. chemmater.0c04796.

42. Zhang X, Cockreham CB, Huang Z, Sun H, Yang C, Marin-Flores OG, et. al. Thermodynamics of Water-Cationic Species-Framework Guest-Host Interactions within Transition Metal Ion-Exchanged Mordenite Relevant to Selective Anaerobic Oxidation of Methane to Methanol. J. Phys. Chem. Lett. 2020; 11 (12): 4774-4784. https://doi.org/10.1021/acs.jpclett.0c01331.

43. Navrotsky A. Progress and New Directions in Calorimetry: A 2014 Perspective. J. Am. Ceram. Soc. 2014; 97 (11): 3349-3359. https://doi.org/10.1111/jace.13278.

44. Sang S, Liu Z, Tian P, Liu Z, Qu L, Zhang Y. Synthesis of Small Crystals Zeolite NaY. Mater. Lett. 2006; 60 (9-10): 1131-1133. https://doi.org/10.1016/j.matlet.2005.10.110.

45. Holmberg BA, Wang H, Yan Y. High Silica Zeolite Y Nanocrystals by Dealumination and Direct Synthesis. Microporous Mesoporous Mater. 2004; 74 (1-3): 189-198. https://doi.org/10.1016/j.micromeso. 2004.06 .018 .

46. Janssen AH, Koster AJ, De Jong KP. Three-dimensional Transmission Electron Microscopic Observations of Mesopores in Dealuminated Zeolite Y. Angew. Chem. Int. Ed. 2001; 40 (6):1102-1104. 
https://doi.org/10.1002/1521-3773(20010316)40:6\%3C1102: :AID-ANIE11020\%3E3.0.C0;2-6.

47. De Jong KP, Zečević J, Friedrich H, De Jongh PE, Bulut M, Van Donk S, et. al. Zeolite Y Crystals with Trimodal Porosity as Ideal Hydrocracking Catalysts. Angew. Chem. Int. Ed. 2010; 49 (52): 10074-10078. https://doi.org/10.1002/ange.2010043.

48. Bordiga S, Regli L, Lamberti C, Zecchina A, Bjørgen M, Lillerud KF. FTIR Adsorption Studies of $\mathrm{H}_{2} \mathrm{O}$ and $\mathrm{CH}_{3} \mathrm{OH}$ in the Isostructural H-SSZ-13 and H-SAPO-34: Formation of H-bonded Adducts and Protonated Clusters. J. Phys. Chem. B. 2005; 109 (16): 7724-7732. https://doi.org/10.1021/jp044324b.

49. Zecchina A, Geobaldo F, Spoto G, Bordiga S, Ricchiardi G, Buzzoni R, et. al. FTIR Investigation of the Formation of Neutral and Ionic Hydrogen-bonded Complexes by Interaction of H-ZSM-5 and H-mordenite with $\mathrm{CH}_{3} \mathrm{CN}$ and $\mathrm{H}_{2} \mathrm{O}$ : Comparison with the H-NAFION Superacidic System. J. Phys. Chem. $1996 ; 100$ (41): 16584-16599. https://doi.org/10.1021/jp960433h.

50. Gao J, Zheng Y, Fitzgerald GB, De Joannis J, Tang Y, Wachs IE, et. al. Structure of $\mathrm{Mo}_{2} \mathrm{C}_{\mathrm{x}}$ and $\mathrm{Mo}_{4} \mathrm{C}_{\mathrm{x}}$ Molybdenum Carbide Nanoparticles and Their Anchoring Sites on ZSM-5 Zeolites. J. Phys. Chem. C. 2014; 118 (9): 4670-4679. https://doi.org/10.1021/jp4106053.

51. Wang D, Lunsford JH, Rosynek MP. Characterization of a Mo/ZSM-5 Catalyst for the Conversion of Methane to Benzene. J. Catal. 1997; 169 (1): 347-358. https://doi.org/10.1006/jcat.1997.1712.

52. Jones AJ, Iglesia E. The Strength of Brønsted Acid Sites in Microporous Aluminosilicates. ACS Catal. 2015; 5 (10): 5741-5755. https://doi:10.1021/acscatal.5b01133.

53. Lakiss L, Vicente A, Gilson JP, Valtchev V, Mintova S, Vimont A, Bedard R, Abdo S, Bricker J. Probing the Brønsted Acidity of the External Surface of Faujasite-Type Zeolites. ChemPhys Chem. $2020 ; 21$ (16): 1873-1881. https://doi:10.1002/cphc.202000062.

54. Tsutsumi K, Mitani Y, Takahashi H. Evaluation of Energy Distribution on a Heterogeneous Surface from Heat of Adsorption and Its Application to the Ammonia/Na-Y Zeolite System. Colloid Polym. Sci. 1985; 263 (10): 838-841. http://doi:10.1007/BF01412962.

55. Hattori H, Arudra P, Abdalla A, Aitani AM, Al-Khattaf SS. Infrared Study of Silanol Groups on Dealuminated High Silica MFI Zeolite to Correlate Different Types of Silanol Groups with Activity for Conversion of 1-Butene to Propene. Catal. Lett. 2020; 150 (3):771-780. https://doi:10.1007/s10562019-02972-8.

56. Hernandez-Tamargo CE, Roldan A, De Leeuw NH. A Density Functional Theory Study of the Structure of Pure-Silica and Aluminium-substituted MFI nanosheets. J. Solid State Chem. 2016; 237: $192-203$. http://doi:10.1016/j.jssc.2016.02.006.

57. Lee EL, Wachs IE. In Situ Spectroscopic Investigation of the Molecular and Electronic Structures of $\mathrm{SiO}_{2}$ Supported Surface Metal Oxides. J. Phys. Chem. C. 2007;111 (39):14410-14425. https://doi.org/ 10.1021/jp0735482.

58. Lee EL, Wachs IE. Molecular Design and in situ Spectroscopic Investigation of Multilayered Supported $\mathrm{M}_{1} \mathrm{O}_{\mathrm{x}} / \mathrm{M}_{2} \mathrm{O}_{\mathrm{x}} / \mathrm{SiO}_{2}$ Catalysts. J. Phys. Chem. C. 2008; 112 (51): 20418-20428. https://doi.org/10.1021/ jp805265m.

59. Tian H, Roberts CA, Wachs IE. Molecular Structural Determination of Molybdena in Different Environments: Aqueous Solutions, Bulk Mixed Oxides, and Supported $\mathrm{MoO}_{3}$ Catalysts. J. Phys. Chem. C. 2010; 114 (33): 14110-14120. https ://doi.org/10.1021/jp103269w.

60. Zheng Y, Tang Y, Gallagher JR, Gao J, Miller JT, Wachs IE, Podkolzin SG. Molybdenum Oxide, Oxycarbide, and Carbide: Controlling the Dynamic Composition, Size, and Catalytic Activity of Zeolite-Supported Nanostructures. J. Phys. Chem. C. 2019; 123 (36): 22281-22292https://doi.org/10.1021/acs.jpcc.9b05449. 
61. Okemoto A, Harada MR, Ishizaka T, Hiyoshi N, Sato K. Catalytic Performance of $\mathrm{MoO}_{3} / \mathrm{FAU}$ Zeolite Catalysts Modified by $\mathrm{Cu}$ for Reverse Water Gas Shift Reaction. Appl. Catal. A Gen. 2020; 117415. https: //doi.org/10.1016/j.apcata.2020.117415.

62. Liu H, Xu Y. $\mathrm{H}_{2}$-TPR Study on Mo/HZSM-5 Catalyst for $\mathrm{CH}_{4}$ Dehydroaromatization. Chinese J. Catal. 2006; 27 (4): 319-323. https://doi.org/10.1016/S1872-2067(06)60020-X.

63. Zhao K, Jia L, Wang J, Hou B, Li D. The Influence of the Si/Al Ratio of Mo/HZSM-5 on Methane Non-oxidative Dehydroaromatization. New J. Chem. 2019; 43(10): 4130-4136. https://doi.org/10.1039/ C9NJ00114J.

64. Spevack PA, McIntyre NS. Thermal Reduction of Molybdenum Trioxide. J. Phys. Chem. 1992; 96 (22): 9029-9035. https://doi.org/10.1021/j100201a062.

65. Brezesinski T, Wang J, Tolbert SH, Dunn B. Ordered Mesoporous $\alpha-\mathrm{MoO}_{3}$ with Iso-oriented Nanocrystalline Walls for Thin-film Pseudocapacitors. Nat. Mater. 2010; 9: 146-151. https://doi.org/10.1038/ nmat2612.

66. McCarron III EM. P-MoO ${ }_{3}$ : a Metastable Analogue of $\mathrm{WO}_{3}$. J. Chem. Soc., Chem. Commun., 1986, 336-338. https://doi.org/10.1039/C39860000336.

67. Cid R, Llambías FJG, Fierro JLG, Agudo AL, Vlllaseñor J. Physicochemical Characterization of $\mathrm{MoO}_{3}$ NaY Zeolite Catalysts. J. Catal. 1984; 89 (2): 478-488. https ://doi.org/10.1016/0021-9517 (84) 90324-5.

68. Robie RA, Hemingway BS. Thermodynamic Properties of Minerals and Related Substances at $298.15 \mathrm{~K}$ and 1 Bar $\left(10^{5}\right.$ Pascals) Pressure and Higher Temperatures. U.S. Government Printing Office, Washington D.C., U.S. 1995. https://doi.org/10.1007/BF00307526.

69. 1. Navrotsky A. Progress and New Directions in High Temperature Calorimetry. Phys. Chem. Minerals. 1977; 2: 89-104. https://doi.org/10.3133/b2131.

70. Navrotsky A. Progress and New Directions in High Temperature Calorimetry Revisited. Phys. Chem. Minerals. 1997; 24: 222-241. https://doi.org/10.1007/s002690050035.

71. Li G, Sun H, Xu H, Guo X, Wu D. Probing the Energetics of Molecule-Material Interactions at Interfaces and in Nanopores. J. Phys. Chem. C. 2017; 121 (47): 26141-26154. https://doi.org/10.1021/acs.jpcc.7b07450. 